Article

\title{
Sustainable and Durable Performance of Pozzolanic Additions to Prevent Alkali-Silica Reaction (ASR) Promoted by Aggregates with Different Reaction Rates
}

\author{
Esperanza Menéndez ${ }^{1}$, Miguel Ángel Sanjuán ${ }^{2, *}$,, Ricardo García-Roves ${ }^{1}\left(\mathbb{0}\right.$, Cristina Argiz ${ }^{2}$ (D) \\ and Hairon Recino ${ }^{1}$ D \\ 1 The Eduardo Torroja Institute for Construction Science (Spanish National Research Council, CSIC), \\ C/Serrano Galvache, 4, 28033 Madrid, Spain; emm@ietcc.csic.es (E.M.); r.gloza@alumnos.upm.es (R.G.-R.); \\ h.recino@ietcc.csic.es (H.R.) \\ 2 Civil Engineering School, Technical University of Madrid (UPM), C/Profesor Aranguren, 3, \\ Ciudad Universitaria, 28040 Madrid, Spain; cg.argiz@upm.es \\ * Correspondence: masanjuan@ieca.es; Tel.: +34-914429166
}

Received: 24 November 2020; Accepted: 15 December 2020; Published: 17 December 2020

check for updates

Featured Application: In this paper, the idea of the sustainability of durable solutions is very much present. The effect of four pozzolanic materials employed in four percentages in mortars made with two different reactive aggregates is assessed regarding alkali-silica reaction (ASR). The findings encountered here will help to optimize the cement-based materials mix design.

\begin{abstract}
The increased use of industrial wastes and by-products to produce concretes and blended cements is a lever to achieve carbon neutrality. Furthermore, they could improve their durability. Some pozzolanic additions can minimize the alkali-silica reaction (ASR), which is a well-known deleterious process that occurs between some reactive aggregates and the alkaline pore solution found in mortars and concretes. This work quantifies the efficiency of four pozzolanic materials (natural pozzolan, P, siliceous coal fly ash, V, silica fume, D, and blast-furnace slag, S) assessed by means of compressive strength testing, open porosity, ASR-expansion measurements, and SEM microscopy. Accelerated expansion tests were performed in mortar bars with a cement/sand ratio of 1/2.25 and a water/cement ratio of 0.47 , two reactive aggregates and a non-reactive one. The major contributions of this paper are: (i) The more aggregate reactivity is, the higher ASR mitigation level was found when additions were added and (ii) The best additions for ASR inhibition are silica fume and fly ash.
\end{abstract}

Keywords: cement replacement; supplementary cementitious materials; microstructure; transport properties; durability; alkali-aggregate reaction (AAR) mitigation; natural pozzolan; siliceous coal fly ash; silica fume; blast-furnace slag

\section{Introduction}

Eco-innovation is any breakthrough which makes progress towards circular economy and mitigation of the climate change. Both aspects are part of sustainable development. The Industrial Strategy for Europe, published in 2020 [1], underscores the prime concern that industries must face to reach the goal of carbon neutrality [2]. Furthermore, Europe plays a crucial role promoting clear requirements for a Zero Waste Circular Economy over the years across several policies.

For instance, the European Commission launched in 2011 the Roadmap to a Resource Efficient Europe [3] with criteria to move towards zero waste in Europe. This EU Communication stipulated 
that incineration with energy recovery should be limited to non-recyclable materials, landfilling should be almost eliminated, and high level of recycling should be ensured. Later, the Communication on Waste-to-Energy [4], published in 2017, showed the role of Waste-to-Energy incineration and it recommended make incineration more expensive. Taxation of such use would therefore be encouraged. In 2018, The Circular Economy Package included a new regulation aiming at recycling 65\% of global municipal waste by 2035. In general, these new targets help to move towards a Zero Waste Circular Economy. Complementarily, the revised Renewable Energy Directive (EU) 2018/2001 [5], approved phase-out subsidies to Waste-to-Energy incineration. In 2020, the Taxonomy regulation excluded Waste-to-Energy incineration from the economic activities which meet the criteria to contribute positively to the climate change mitigation because it damages the circular economy [6]. Within this context, pyrolysis of plastics and tires is an upcoming industry which can turn these wastes into energy with lower emissions compared to full combustion [7]. Therefore, this technology can solve the environmental problem of disposing these wastes. In addition, it is a source of by-products such as pyrolysis oil, pyrolysis gas and so on.

The increase use of industrial wastes and by-products as supplementary cementitious materials to produce concretes and blended cements is a lever to achieve net zero carbon dioxide emissions [8]. In this respect, it is striking that carbon neutrality will be reached through the outright clinker, cement and concrete value chain by 2050 in agreement with the European Green Deal objectives [2,9]. In addition, the EU circular economy action plan [9] promotes increasing circularity, natural resources usage reduction and wastes generation minimization. Accordingly, the cement and concrete sectors are playing a key role in circularity due to the potentially increase use of by-products and industrial wastes to produce clinker, cement and concrete [10]. This transition process will need a regulatory framework to enhance this transformation not limited to taxonomy [8].

There are two major advantages of using supplementary cementitious materials in concretes and cements and enhancing sustainability and the first of these is the increase of durability, and then, increasing the service life of concrete structures. This aspect is based largely on the pozzolanic reaction developed with many of these industrial wastes. A second aspect is through Portland clinker lowering. Cement production is responsible for $7.4 \%$ of the worldwide carbon dioxide emissions (2.9 Gtons) [11]. Therefore, the clinker factor increase will allow a mitigation of such emissions [8]. Direct emissions decreased in Europe from 783 to $667 \mathrm{~kg} \mathrm{CO}_{2} / \mathrm{t}$ cement between 1990 and 2018. Within this context, the reduction of the clinker to cement ratio has been an important lever for decarbonization. In addition, carbon dioxide uptake due to the mortar and concrete carbonation should be taken into account in the carbon dioxide net balance for the cement and cement-based materials [11].

Aggregates are granular materials, such as sand and gravel, that fill between the seventy and eighty percent of the concrete volume. Therefore, they are its major ingredient. For a good concrete mix, aggregates should be inert. Nevertheless, some of them react in alkaline environments leading to the well-known alkali-silica reaction (ASR) [12], which is a deleterious process ocurring between the amorphous silica present in the reactive aggregates [13] and the alkaline constituents of the pore solution, such as sodium, potassium, and hydroxyl ions, among others [14].

A hydrated ASR gel is the reaction product, which can imbibe water and swell when enough reactive silica, alkali content and moisture are present in the system. Accordingly, the internal swelling pressure promotes expansion of the cement-based material, cracking and loss of mechanical strength and durability in concrete structures. Shin et al. reported three types of cracks in the inner region i.e., isolated cracks without ASR gel which appear in the cement the paste or in the aggregate grains or at the aggregate-paste interface (type 1); cracks in aggregate grains filled with ASR gel (type 2); and cracks without ASR gel linked to type 2 cracks that are formed in the paste or at the interface [15]. Understanding the mechanism of the ASR has practical implications, of to propose potentially preventive measures to minimize ASR impact. ASR occurs between the reactive silica present in the reactive aggregates and the alkaline pore solution of concrete. 
The main sources of alkalis are the Portland cement, fine and coarse aggregates and the surrounding environment. These alkalis with water form soluble alkali hydroxides [14]. Normally, the silica in the form of quartz is chemically inert. Nevertheless, poorly crystalline silica, present in opal, chert, chalcedony and so on, reacts with the pore solution to form amorphous hydrous silica. ASR proceeds according to the following steps [14]. Firstly, siloxane bonds (Si-O-Si) breakup by hydroxyl ions is produced to generate alkali silicate gel and silicic acid (silanol bonds). Afterwards, alkali-silica gel moves from aggregate to cement paste and reacts with the calcium ions forming alkali-calcium silicate hydrate gel. Secondly, alkali-silica gel imbibes water from the surroundings and swell leading to an increase of the internal swelling pressure and material expansion, which may produce aggregate and cement paste cracking and concrete damage.

Recently, the use of construction and demolition wastes (CDW) and recycled aggregates (RA) has become a topic of great interest in the circular economy context [16,17]. It is suggested that the possibility of having potentially reactive aggregate will be increased using RA [17].

Potential preventive measures to avoid the ASR include the use of blended cements made with adequate pozzolans [18-22] or low-alkali cements, reactive aggregate beneficiation [23], optimize the structural design to avoid the concrete wetting and so on. All of them can be considered as levers to achieve the expected concrete mix design improvement and their effectiveness depends on the reaction mechanism and its intensity. In addition, the current widespread use of blended cements in the construction industry finds its recent promotion in the challenge to meet the target of holding temperature rises to $1.5^{\circ} \mathrm{C}$ by the end of the 21st century [8].

Pozzolanic additives contain a certain content of alkalis, however, it has been reported that blended cements control ASR expansion because they are able to bind alkalis and to limit the further availability for reaction with reactive aggregates [24,25]. Accordingly, ASR mitigation effectiveness is dependent on the chemical composition of the blended cement. Alkalis are present in the pore solution or bound by the blended cement hydration products or added to ASR gel. Therefore, the chemical characteristics of the addition present in the binder and replacement level will influence the pore solution concentration. Such additions lower the alkali-hydroxides concentration in the pore solution of concretes [25-28]. The higher replacement level is, the lower concentration was monitored. Low replacement levels of silica fume (5-10\%) exhibited hydroxyl concentration drop in the pore solution during the first 28 days. Nevertheless, it increases after three months [27]. This long-term release of alkalis was not recorded for blended cements with blast-furnace slag or coal fly ash. It could be attributed to the presence of alumina in these two additions, i.e., alumina incorporation in the C-S-H gel forms C-A-S-H gel with a high alkali-binding capacity [29]. Nevertheless, the effect of the alumina on the alkali-binding capacity is still unclear [25].

There is an aspect in relation to which we can say that the pozzolanic reaction is similar to ASR. Reactive silica in the pozzolanic addition reacts with alkali hydroxides producing alkali-silica gel. Later on, calcium exchanges for sodium and potassium in mentioned gel leading to the formation of C-S-H gel with a low $\mathrm{Ca} / \mathrm{Si}$ ratio compared to that of the Portland cement pastes. Thus, a shorter turnaround time and the absence of expansion in the pozzolanic reaction is the main difference with the ASR. Absence of expansion is due to the high fineness. This fact allows the alkali-silica gel formed in the pozzolanic reaction to be distributed throughout the blended cement. By contrast, larger aggregates form some local deposits of alkali-silica gel that turn into areas of expansion [14].

Summing up, the use of some Portland cement constituents, such as silica fume, metakaolin and siliceous fly ash, was found effective in mitigating ASR deleterious effects $[24,25]$. The reasons for mentioned positive performance can be summarized as follows:

- Reducing the clinker content in the blended cement, the concentration of alkali metals is lowered in the pore solution (dilution effect).

- The additional pozzolanic calcium silicate hydrates formed (for short C-S-H gel), with lower $\mathrm{Ca} / \mathrm{Si}$ ratio, provides a larger amount of nucleation sites for alkali's absorption, i.e., higher alkali 
binding capacity is achieved, then limiting the ASR gel production [26]. This C-S-H gel partially fill the capillary pores densifying the cement paste and the interfacial transition zone (ITZ) [27].

- The reduction of permeability and diffusivity of the mortars and concretes by densification the cement paste and ITZ enhanced by the pozzolanic reaction, lowers the external alkalis and water ingress through the capillary pores.

- Mentioned pozzolanic materials also have a great influence on the of ASR gel properties. For instance, Monteiro et al. [28] reported that gels with high $\mathrm{CaO} / \mathrm{Na}_{2} \mathrm{O}_{\text {eq }}$ ratio exhibited lower swelling capacity than gels with low $\mathrm{CaO} / \mathrm{Na}_{2} \mathrm{O}_{\text {eq }}$ ratio. Accordingly, silica fume and coal fly ash shrink the swelling capacity.

- Finally, Hong and Glasser reported that the presence of $\mathrm{Al}$ in $\mathrm{C}-\mathrm{S}-\mathrm{H}$ gel improves the alkali binding capacity [29]. Therefore, the alumina from the coal fly ash can be dissolved into the mortar or concrete pore solution and further incorporated into the $\mathrm{C}-\mathrm{S}-\mathrm{H}$ gel during the hydration of the cement and the pozzolanic reactions involved in the $\mathrm{C}-\mathrm{A}-\mathrm{S}-\mathrm{H}$ gel formation. Nevertheless, high levels of aluminum which may be present in the pore solution could deplete the silica dissolution rate [30], due to the aluminum absorption on the silica surfaces leading to an aluminosilicate layer generation [31].

Consequently, the main objective of this work is to assess the effect of natural pozzolan, $\mathrm{P}$, siliceous coal fly ash, V, silica fume, D, and blast-furnace slag, $\mathrm{S}$ on the suppression of ASR-induced expansion in mortar specimens made using one alkali-bearing reactive aggregate, one moderate reactive aggregate and one alkali-free non-reactive aggregate.

\section{Materials and Methods}

\subsection{Materials}

A Portland cement type CEM I 42.5N (EN 197-1 [32]), provided by The Cementos Portland Valderrivas Group and produced in the cement plant located in Hontoria (Palencia, Spain), was used to manufacture several blended cements. Such cements contained natural pozzolan, $\mathrm{P}$, siliceous coal fly ash, V, silica fume, D, or ground granulated blast-furnace slag, S.

Blended cements were prepared by mixing CEM I with the percentage of additive shown in Table 1 , i.e., for silica fume (SF) blended cements, the mixes contain 3\%SF + 97\%CEM I, 5\%SF + 95\%CEM I, $7 \% \mathrm{SF}+93 \% \mathrm{CEM} \mathrm{I}, 10 \% \mathrm{SF}+90 \% \mathrm{CEM} \mathrm{I}$ and $15 \% \mathrm{SF}+85 \% \mathrm{CEM} \mathrm{I}$, respectively.

Table 1. Percentage of the additive in the blended cement.

\begin{tabular}{cccccc}
\hline Additive & \multicolumn{5}{c}{ Percentage of the Additive in the Blended Cement } \\
\hline Silica fume, D & $3 \%$ & $5 \%$ & $7 \%$ & $10 \%$ & $15 \%$ \\
Siliceous coal fly ash, V & $5 \%$ & $10 \%$ & $20 \%$ & $30 \%$ & $40 \%$ \\
Ground granulated & $5 \%$ & $10 \%$ & $20 \%$ & $30 \%$ & $40 \%$ \\
blast-furnace slag, S & $10 \%$ & $20 \%$ & $30 \%$ & $40 \%$ & $50 \%$ \\
Natural pozzolan, P & & & &
\end{tabular}

The low levels chosen for silica fume, D, are a consequence of its high reactive silicon content that will be involved subsequently in the pozzolanic reaction. In any case, the proportions selected are substantial enough to adequately represent the main types of cements that it illustrates. Distilled water was utilized for all the mortar mixes.

The aggregates utilized in this study were acquired from three different quarries. Three types of siliceous aggregates were chosen to make the testing mortars (Figure 1). The first one is an alkali-bearing reactive aggregate according to UNE 146508 [33], ASJ_12 (siliceous pebbles, 4-6 mm, supplied by El Aljibe quarry, located in Almonacid de Toledo, Spain. The second one presented a moderate reactivity, VB_1 (siliceous gravel, 6-12 mm, supplied by Dueñas quarry, located in Palencia, Spain). The third 
one was an alkali-free non-reactive aggregate, ASJ_2 (siliceous sand, 0-2 mm, provided by El Puente quarry, located in Aranjuez, Madrid, Spain).

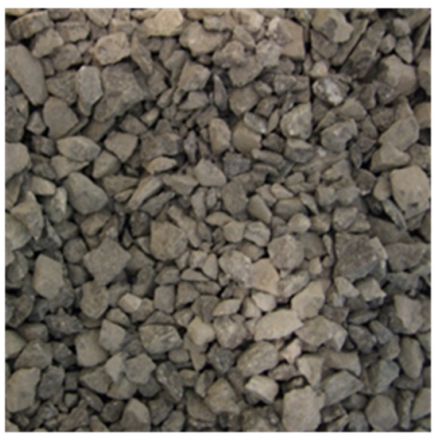

(a)

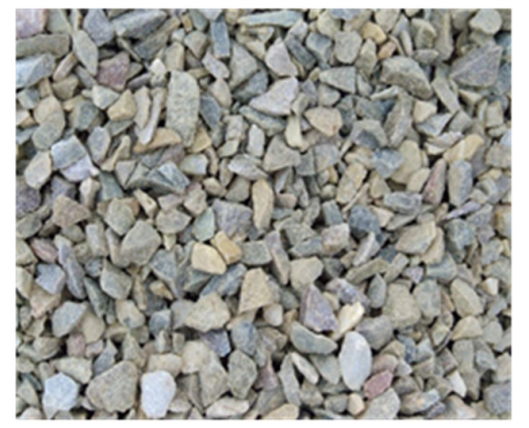

(b)

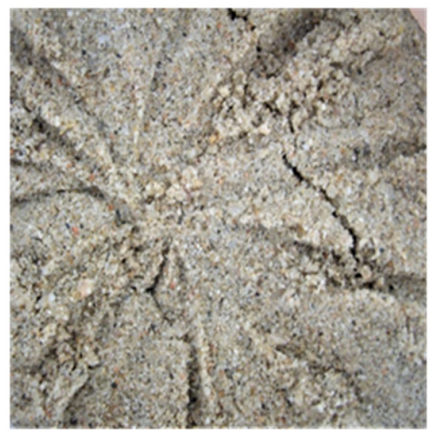

(c)

Figure 1. Siliceous aggregates employed in the present research work: (a) ASJ_12 (siliceous pebbles, 4-6 mm); (b) VB_1 (siliceous gravel, 6-12 mm); (c) ASJ_2 (siliceous sand, 0-2 mm).

\subsection{Chemical and Mineralogical Characterization of the Materials}

Chemical composition of the CEM I, natural pozzolan, P, siliceous coal fly ash, V, silica fume, D, and ground granulated blast-furnace slag, $\mathrm{S}$, is shown in Table 2; whereas the chemical compositions for the three tested aggregates are given in Table 3. The chemical analyses were performed by XRF with a 88 Tigger $4 \mathrm{~kW}$ model instrument (Bruker, Billerica, Massachusetts, USA). Loss on ignition (LOI) and chloride ion contents were determined according to the European standard EN 196-2 [34].

The effect of equivalent sodium oxide ratio, $\mathrm{Na}_{2} \mathrm{O}_{\text {eq }}$, of Portland cement and additions on ASR properties should be considered. The highest $\mathrm{Na}_{2} \mathrm{O}_{\text {eq }}$ ratio was found in the coal fly ash $(4.56 \%)$ followed by the silica fume (3.22\%) as shown in Table 2. The role of $\mathrm{Na}_{2} \mathrm{O}_{\text {eq }}$ ratio on the mechanical strength development and flowability of cement-based materials is well-known, but also it has a deleterious effect regarding the ASR. In addition, Menéndez et al. [35] discussed the contribution of the alkali release from aggregates to ASR. The reactive aggregate presented the largest content of alkalis $\left(\mathrm{Na}_{2} \mathrm{O}_{\text {eq }}=5.89 \%\right)$ followed by the non-reactive one $\left(\mathrm{Na}_{2} \mathrm{O}_{\text {eq }}=3.51 \%\right)$.

Table 2. Chemical composition of the CEM I, natural pozzolan, P, siliceous coal fly ash, V, silica fume, $\mathrm{D}$, and ground granulated blast-furnace slag, $\mathrm{S}$.

\begin{tabular}{cccccc}
\hline Parameter & CEM I 42.5 N & $\mathbf{V}$ & $\mathbf{S}$ & $\mathbf{D}$ & $\mathbf{P}$ \\
\hline $\mathrm{Al}_{2} \mathrm{O}_{3}$ & 3.65 & 23.16 & 12.16 & - & 13.15 \\
$\mathrm{CaO}$ & 64.49 & 5.75 & 41.55 & 0.60 & 12.98 \\
$\mathrm{Cl}^{-}$ & 0.03 & - & - & 0.06 & - \\
$\mathrm{Cr}_{2} \mathrm{O}_{3}$ & 0.02 & 0.17 & - & - & - \\
$\mathrm{Fe}_{2} \mathrm{O}_{3}$ & 3.96 & 5.93 & 0.39 & 0.14 & 12.75 \\
$\mathrm{~K}_{2} \mathrm{O}$ & 0.64 & 0.96 & 0.48 & 3.03 & 0.56 \\
$\mathrm{MgO}$ & 1.27 & 1.96 & 6.96 & 0.33 & 9.62 \\
$\mathrm{Mn}_{2} \mathrm{O}_{3}$ & 0.05 & 13.35 & 48.97 & 40.06 & - \\
$\mathrm{Na}_{2} \mathrm{O}$ & 0.12 & 3.93 & 0.17 & 1.23 & 0.63 \\
$\mathrm{P}_{2} \mathrm{O}_{5}$ & 0.18 & 0.67 & - & - & 1.26 \\
$\mathrm{SiO}_{2}$ & 20.80 & 52.17 & 35.13 & 91.31 & 42.82 \\
$\mathrm{SO}_{3}$ & 2.33 & 0.36 & 1.86 & - & 0.00 \\
$\mathrm{SrO}$ & 0.06 & 0.10 & 0.05 & - & 0.12 \\
$\mathrm{TiO}_{2}$ & 0.19 & 0.92 & 0.56 & - & 3.62 \\
$\mathrm{ZnO}$ & 0.01 & 0.02 & - & - & 0.02 \\
$\mathrm{ZrO}_{2}$ & - & 0.03 & 0.02 & - & 0.05 \\
$\mathrm{LOI}^{1}$ & 2.21 & 3.80 & 0.45 & 3.29 & 2.21 \\
$\mathrm{Na}_{2} \mathrm{O}_{\text {eq }}$ & 0.54 & 4.56 & 0.49 & 3.22 & 0.99 \\
\hline
\end{tabular}

${ }^{1}$ LOI: Loss on ignition; $\mathrm{Na}_{2} \mathrm{O}_{\text {eq }}=\mathrm{Na}_{2} \mathrm{O}+0.658 \mathrm{~K}_{2} \mathrm{O}$. 
Table 3. Chemical composition for the three tested aggregates: (a) non-reactive siliceous sand, ASJ_2; (b) siliceous gravel with moderate reactivity, VB; (c) high-reactive siliceous pebbles, ASJ_12.

\begin{tabular}{|c|c|c|c|}
\hline Parameter & ASJ-2 & VB-1 & ASJ-12 \\
\hline $\mathrm{SiO}_{2}$ & 73.61 & 78.06 & 60.55 \\
\hline $\mathrm{Al}_{2} \mathrm{O}_{3}$ & 6.48 & 3.64 & 15.80 \\
\hline $\mathrm{Fe}_{2} \mathrm{O}_{3}$ & 0.88 & 1.28 & 6.83 \\
\hline $\mathrm{K}_{2} \mathrm{O}$ & 4.02 & 0.66 & 4.58 \\
\hline $\mathrm{CaO}$ & 9.25 & 9.82 & 4.30 \\
\hline $\mathrm{Na}_{2} \mathrm{O}$ & 0.87 & 0.14 & 2.88 \\
\hline $\mathrm{MgO}$ & 0.20 & 0.30 & 2.47 \\
\hline $\mathrm{TiO}_{2}$ & 0.09 & 0.26 & 1.00 \\
\hline $\mathrm{P}_{2} \mathrm{O}_{5}$ & 0.06 & 0.12 & 0.45 \\
\hline $\mathrm{BaO}$ & 0.04 & - & 0.09 \\
\hline $\mathrm{MnO}$ & 0.01 & 0.01 & 0.08 \\
\hline $\mathrm{Cr}_{2} \mathrm{O}_{3}$ & 0.07 & 0.04 & 0.04 \\
\hline $\mathrm{SrO}$ & 0.01 & - & 0.03 \\
\hline $\mathrm{ZrO}_{2}$ & - & - & 0.03 \\
\hline $\mathrm{SO}_{3}$ & 0.06 & 0.05 & 0.02 \\
\hline $\mathrm{Rb}_{2} \mathrm{O}$ & 0.02 & - & 0.02 \\
\hline $\mathrm{Cl}^{-}$ & 0.01 & - & 0.02 \\
\hline LOI $^{1}$ & 4.31 & 5.59 & 0.81 \\
\hline $\mathrm{Na}_{2} \mathrm{O}_{\mathrm{eq}}{ }^{1}$ & 3.51 & 0.58 & 5.89 \\
\hline $\begin{array}{l}\text { Main crystalline } \\
\text { component }\end{array}$ & Quartz & Quartz & Quartz \\
\hline $\begin{array}{l}\text { Minority crystalline } \\
\text { components }\end{array}$ & $\begin{array}{c}\text { Feldspars (Albite type) } \\
\text { Black mica (Biotite) }\end{array}$ & $\begin{array}{l}\text { Feldspars (Microcline) } \\
\text { Carbonates (Calcite) }\end{array}$ & Carbonates (Calcite type) \\
\hline
\end{tabular}

Mineralogical characterization was performed by X-ray diffraction (XRD). Thus, the crystalline compounds present in the aggregates were determined by XRD. Diffraction data of the aggregates were recorded using a D8 Advance powder crystal X-ray diffractometer (Bruker) with $2.2 \mathrm{KW} \mathrm{Cu}$ anode ceramic X-ray tube. Crystalline compounds were identified with the DIFFRAC.EVA v4.2.1 software which supports a reference pattern database derived from the Crystallography Open Database (COD) for phase identification. The analyses were carried out on a representative sample of each aggregate. The test sample was ground and sieved on a sieve, either by hand or by mechanical means. Then, a grain size lower than $80 \mu \mathrm{m}$ was achieved. The identification, chemical composition and aggregate type of each aggregate are shown in Table 3.

\subsection{Mechanical Strenth and Open Porosity}

The mechanical assessment was performed at 2, 7 and 28 days by means of the compressive strength method defined in the European standard EN 196-1 [36]. Open porosity was determined following the method prescribed in the Spanish standard UNE 83980 [37] and calculated according to Equation (1), where $\mathrm{m}_{1}$ is the weight of the sample after drying $\left(110{ }^{\circ} \mathrm{C} \pm 5^{\circ} \mathrm{C}\right.$ for $\left.24 \mathrm{~h}\right), \mathrm{m}_{2}$ is the weight of the sample after vacuum conditions and $\mathrm{m}_{3}$ is the apparent weight of the mortar sample (hydrostatic weight, i.e., underwater weighing):

$$
\text { Open porosity, } \%=\frac{m_{2}-m_{1}}{m_{2}-m_{3}} \cdot 100
$$

\subsection{Alkali-Aggregate Reactivity Test Method (Blended Cement Mortar-Bar Method)}

The alkali-aggregate test method used in this research work is detailed in the Spanish standard UNE 146508 [33] equivalent to ASTM C-1260 [38]. In preparing the mortar bar specimens, the coarse aggregates were washed, dried $\left(105^{\circ} \mathrm{C} \pm 5{ }^{\circ} \mathrm{C}\right)$, crushed, and sieved into the five fractions (from 
$0.160 \mathrm{~mm}$ to $5 \mathrm{~mm}$ ) as per the requirement of UNE 146508 [33]. Then, the potential reactivity of the three aggregates in the mortars made with the 25 cement mixes shown in Table 1 was evaluated in three mortar prisms $\left(2.5 \times 2.5 \times 28.5 \mathrm{~cm}^{3}\right)$ for each mixture. They were prepared mixing $400 \mathrm{~g}$ of cement elaborated with the four pozzolanic materials and $900 \mathrm{~g}$ of aggregate with a water-to-cement ratio (by weight) of 0.47 , and the graded aggregates to total cement ratio (by weight) of 2.25. Special molds were used with a stainless-steel gauge stud into both ends of the longitudinal section of the prism. The effective gauge length was $254 \pm 2.5 \mathrm{~mm}$. The mortar test specimens were demolded after $24 \mathrm{~h}$, and then, stored immersed in water in closed containers which were placed in an oven maintaining the temperature of $80^{\circ} \mathrm{C} \pm 1{ }^{\circ} \mathrm{C}$ for $24 \mathrm{~h}$. Thereafter, they were removed from the containers for which the zero readings were recorded. Afterward, the prisms were submerged in the $1 \mathrm{~N} \mathrm{NaOH}$ soak solution at $80^{\circ} \mathrm{C} \pm 1{ }^{\circ} \mathrm{C}$ in plastic containers held in an oven at $80^{\circ} \mathrm{C} \pm 1{ }^{\circ} \mathrm{C}$ for a further fourteen days. Subsequent expansion readings were made from two to 14 days in accordance with UNE 146508 [33]. However, additional readings were measured over a 90-day period instead of the conventional 14-day period prescribed by the standard. Mortar expansion was calculated according to Equation (2), and the average expansion of the three prisms for each exposure time is given as the mortar expansion result:

$$
\text { Mortar bar expansion }(\%)=\frac{\left(\mathrm{L}_{n}-\mathrm{L}_{0}\right)}{\mathrm{L}_{c}} \times 100
$$

where $\mathrm{L}_{n}$ is the length at the testing time, $\mathrm{L}_{0}$ is the initial length after $24 \mathrm{~h}$ of water immersion at $80{ }^{\circ} \mathrm{C} \pm 1{ }^{\circ} \mathrm{C}, \mathrm{L}_{c}$ is the calibration length $\left(\mathrm{L}_{c}=254 \mathrm{~mm}\right.$ according to UNE 80113 [39]).

The ASR classifications of the aggregates were evaluated based on the 14-day expansion upper limit of mortar bars of $0.10 \%$ (non-reactive aggregate), prescribed by the Spanish standard UNE 146508 [33]. Expansions over $0.20 \%$ indicate a potentially reactive aggregate. Nevertheless, additional 28-day expansion evaluation is made when the 14-day expansion results are between $0.10 \%$ and $0.20 \%$. If it is beyond $0.20 \%$ at 28 days, the aggregate is considered potentially reactive.

\subsection{Microanalysis of Pozzolanic Cement Mortars}

Following the 90-days accelerated mortar bar test expansion measurement, mortar prisms were sectioned using a water-cooled diamond saw to obtain mortar samples. Afterwards, mortar sections were further reduced in size for examination by scanning electron microscopy (SEM) using backscattered electron imaging contrast, using a low-speed saw with propanol lubricant to produce approximately $10 \times 10 \times 10 \mathrm{~mm}$ mortar specimens. Then, they were impregnated with a low-viscosity epoxy using a vacuum system and oven-curing at $55^{\circ} \mathrm{C}$, polished, sputter-coated with gold, and examined using a JSM-5400 system (JEOL, Akishima, Tokyo, Japan) equipped with three detectors: secondary electrons, backscattered electron and an EDX Oxford EDS Link energy dispersive X-ray spectrometer (Oxford Instruments Industrial Products Limited, Oxon, UK).

\section{Results and Discussion}

\subsection{Mechanical Performance and Open Porosity}

Compressive strength tests were performed for all the mortars made with three aggregates (non-reactive siliceous sand, ASJ_2 (Figure 2); siliceous gravel with moderate reactivity, VB (Figure 3); and a reactive siliceous pebble, ASJ_12 (Figure 4)), and blended cements Mechanical performance was assessed at 2, 7 and 28-days following the procedure prescribed in the European standard EN 196-1 [36]. 


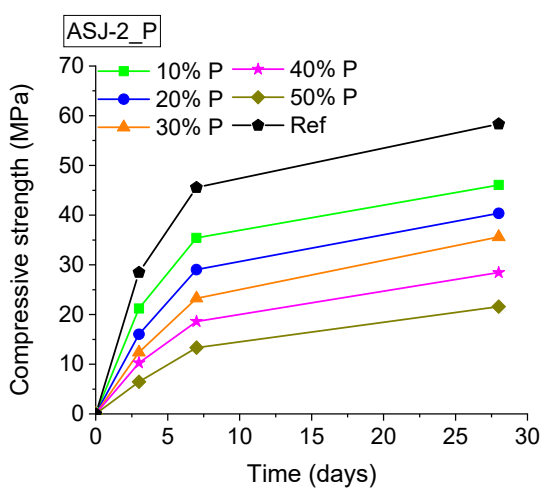

(a)

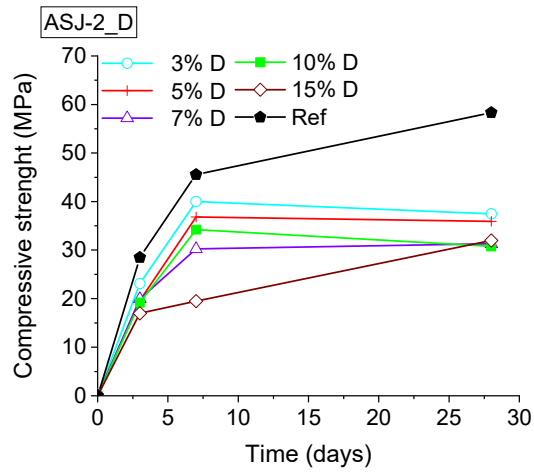

(c)

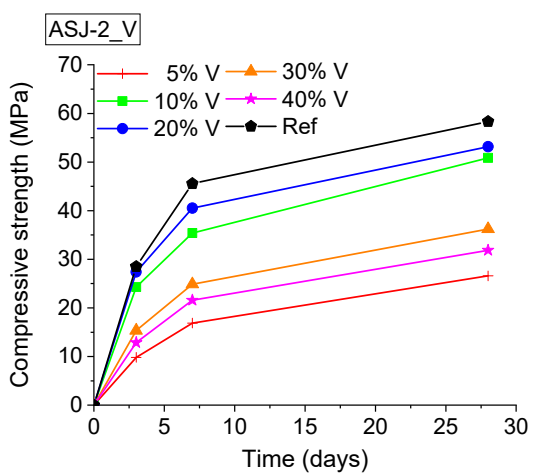

(b)

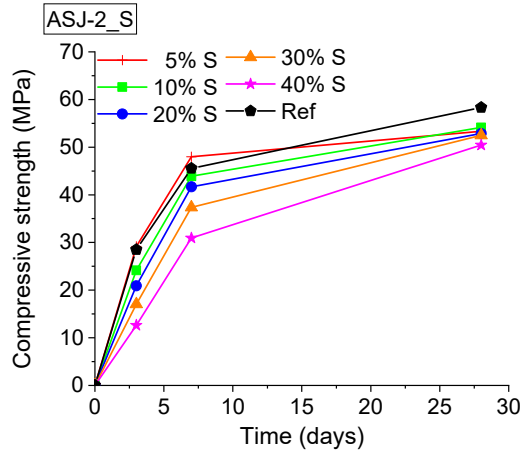

(d)

Figure 2. Compressive strength results of the mortars made with the non-reactive siliceous sand, ASJ_2, and four additions mixed in four percentages of 20\%, 30\%, 40\% and 50\%: (a) natural pozzolan, P; (b) siliceous coal fly ash, V; (c) silica fume, D; (d) blast-furnace slag, S.

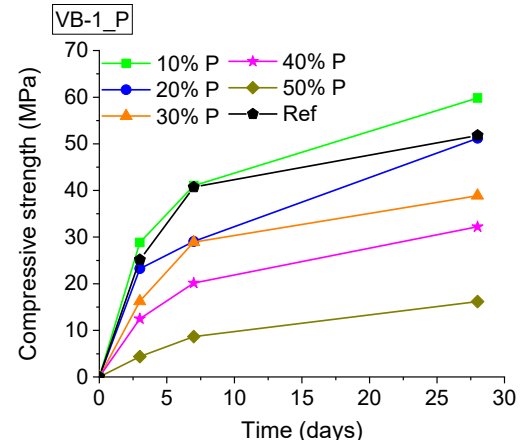

(a)

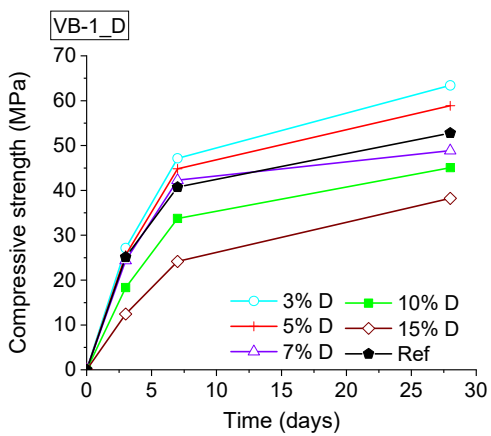

(c)

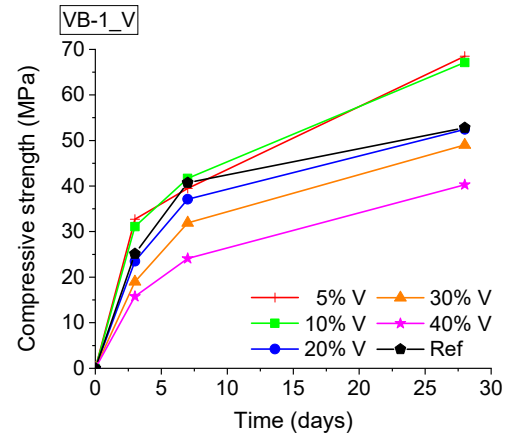

(b)

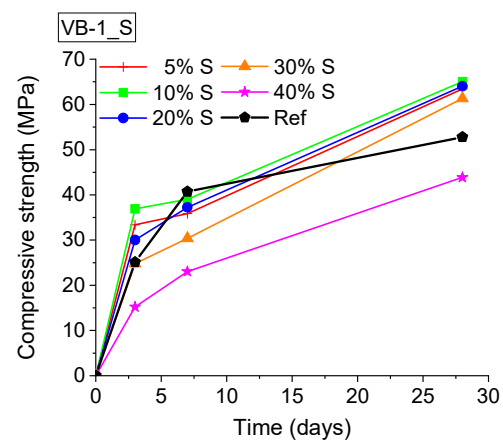

(d)

Figure 3. Compressive strength results of the mortars made with the siliceous gravel with moderate reactivity, $\mathrm{VB}$, and four additions mixed in four percentages of $20 \%, 30 \%, 40 \%$ and $50 \%$ : (a) natural pozzolan, $\mathrm{P}$; (b) siliceous coal fly ash, V; (c) silica fume, D; (d) blast-furnace slag, S. 


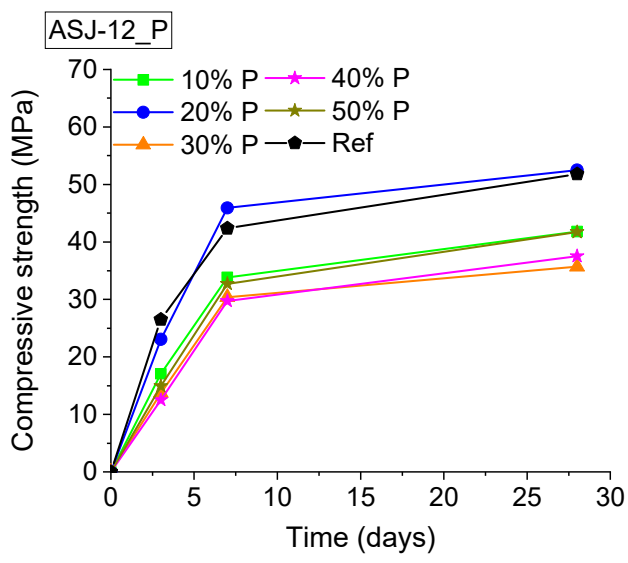

(a)

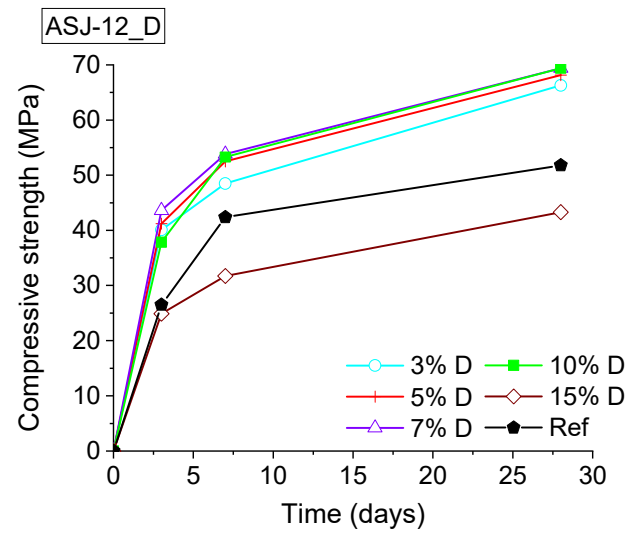

(c)

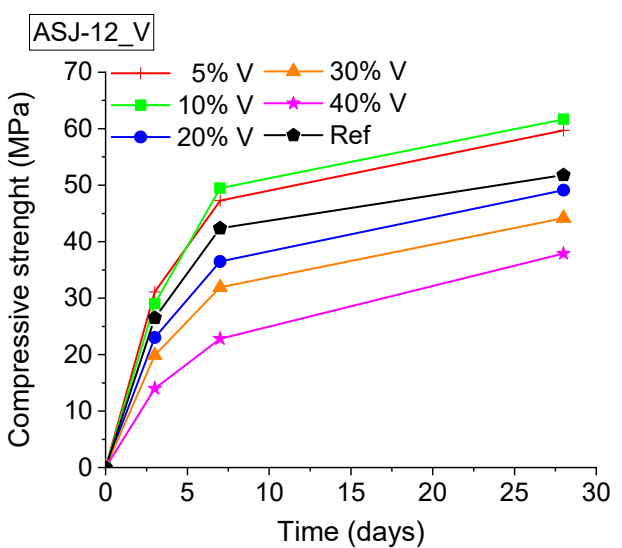

(b)

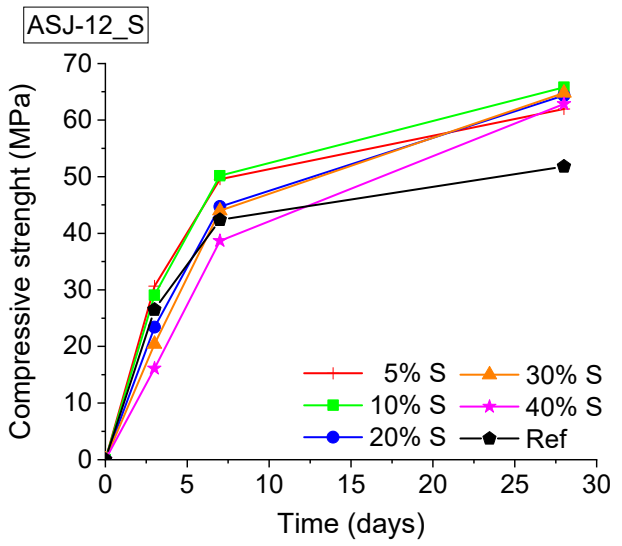

(d)

Figure 4. Compressive strength results of the mortars made with the reactive siliceous pebbles, ASJ_12, and four additions mixed in four percentages of $20 \%, 30 \%, 40 \%$ and $50 \%$ : (a) natural pozzolan, P; (b) siliceous coal fly ash, V; (c) silica fume, D; (d) blast-furnace slag, S.

With regard to the mortar mixes made with the non-reactive aggregate, it was found that the reference mortar had the highest compressive strength at 2, 7 and 28 days in comparison with the mortar mixes made with the pozzolanic additions. Moreover, the higher the addition amount in the mortar mix, the lower the mechanical strength. In the case of the natural pozzolan mortar mixes, the reduction of compressive strength is proportional to the increase of addition in the mix from $10 \%$ to $50 \%$ (Figure 2). However, for the coal fly ash mixes two groups can be differentiated: mortars with low amount of addition (5-20\% V) presenting compressive strength results somewhat similar to that of the reference mortar, and mortars with high coal fly ash content $(30-50 \% \mathrm{~V})$ with much lower compressive strength performance and quite similar to those found in the natural pozzolan mixes with high amount of addition (30-50\% P). As expected, mortars with a high content of additions present low early strength and a quite slow compressive strength development.

Higher compressive strength results were expected in the silica fume mortar mixes with low percentages of replacement $(3-10 \% \mathrm{D})$ due to the high fineness and amorphous silicon dioxide content found in the silica fume. Both parameters lead to better reactive characteristics. Papadakis found that the final strength gain in mortars made with silica fume is proportional to the glass content [40]. However, this unexpected result shown in Figure 2 can be attributed to the agglomeration effect reported in the literature [41]. The reaction mechanism of the silica fume can be outlined saying that small particles of silica fume build up agglomerations which will be completely coated on the outside with a gel-like layer. Then, water is incorporated in this layer, which is a key reason why silica fume uptake water quickly [42]. Accordingly, mortars with silica fume exhibit a high-water demand that may result in a stiffer mortar mix, which reduces the workability and promotes potential molding problems. 
Mitchell et al. [43] found unreacted silica fume particles in pastes with $5 \%$ of silica fume after 180 days of curing. This supports the low pozzolanic reaction rate of silica fume due to an agglomeration of nanoparticles [44].

In addition, silica fume acts as a filler in mortars with high contents of this blended cement constituent [45]. Therefore, in these cases it does not have a significant role in the strength gain. The reason is because silica fume, which is composed of submicron particles consisting of more than $90 \%$ amorphous silica, reacts with the $\mathrm{Ca}(\mathrm{OH})_{2}$ produced by the Portland cement hydration and is consumed faster than in the case of natural pozzolan, $\mathrm{P}$, siliceous coal fly ash, $\mathrm{V}$, and blast-furnace slag, $\mathrm{S}$ [41]. Accordingly, only about $10 \%$ of silica fume is able to react with the $\mathrm{Ca}(\mathrm{OH})_{2}$ to form $\mathrm{C}-\mathrm{S}-\mathrm{H}$ gel and all the rest performs as a filler [46].

With regard to the blast-furnace slag cements, it was observed the best mechanical results of the blended cements for all the ages and the three aggregates. Moreover, high 28-days compressive strength results, over $40 \mathrm{MPa}$, can be achieved with high blast-furnace slag levels of 30-50\%.

The reference mortars made with CEM I $42.5 \mathrm{~N}$ and reactive aggregates (moderate and high-reactive) presented lower compressive strength results (about $50 \mathrm{MPa}$ ) than those homologous mortars made with the non-reactive aggregate $(60 \mathrm{MPa})$. In addition, a synergetic effect between both reactive aggregates and the pozzolanic materials has been found at 28-days. Mortars with low amount of addition (3-10\%) for P, V and D presented higher 28-days compressive strength results than the reference one. About the blended cements made with blast-furnace slag, mentioned synergetic effect seems to be stronger. Consequently, all the results at 28 days (except the $5 \% \mathrm{~S}$ mortar made with the moderate reactive aggregate) are over the reference value (50 MPa).

ASR gel fills the pores and causes an internal tensile stress generating cracks when this tensile stress is higher than the tensile stress of the mortar. Accordingly, mechanical properties of the concrete are affected by ASR gel formation, which can significantly reduce the durability and serviceability of the concrete structures. The level of this reduction depends on the type, size, chemical and physical characteristics, and amount of reactive aggregate [47,48]. Furthermore, it is different for compressive, flexural, or tensile strength. Given that, tensile strength and modulus of elasticity present the highest susceptibility to ASR attack [49]. Furthermore, mechanical properties could be considered as an indirect method for ASR progress assessment. It has been reported compressive strength reduction in high and moderate reactive aggregates. Nevertheless, they were more significant in highly reactive aggregates compared to the moderately reactive ones [47]. By contrast, some studies reported no significant effect on the compressive strength [50]. These results should be justified by the testing conditions. On the other hand, it has been reported that multiaxial compressive strength of mortars made with reactive aggregates and exposed to $60^{\circ} \mathrm{C}$ and $95 \% \mathrm{RH}$ is higher than the multiaxial compressive strength of non-reactive mortars (about 25\%) [51]. This fact is attributed to the higher the microstructural compactness achieved because the ASR gel fills the capillary pores and the interfacial transition zone (ITZ) and it decreases its weakness.

Open porosity of the mortars made with the three aggregates and four additions is shown in Figure 5 . The open porosity is found to be about $15 \%$ for all the mixes except for mortars made with aggregates with moderate reactivity and natural pozzolan $(20 \%, 30 \%$ and $40 \%)$ or with non-reactive aggregate and coal fly ash (30\% and $40 \%)$, which presented higher porosities between $23 \%$ and $30 \%$. These results did not follow any clear trend. Mortars with low levels of blast-furnace slag $(5 \%$ and $10 \%$ ) or silica fume ( $3 \%$ and $5 \%$ ) had open porosities slightly below $15 \%$, which means that a denser microstructure is reached with the incorporation of $\mathrm{S}$ or $\mathrm{D}$ to the mortar. Furthermore, with increasing silica fume content from $10 \%$ to $50 \%$ the open porosity gradually increases from $15 \%$ to slightly above $25 \%$. This fact justifies the low compressive strength of the silica fume mortars recorded at 28 days. 


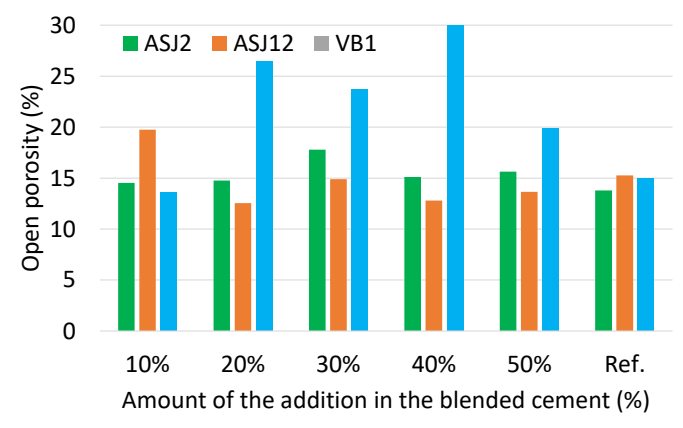

(a)

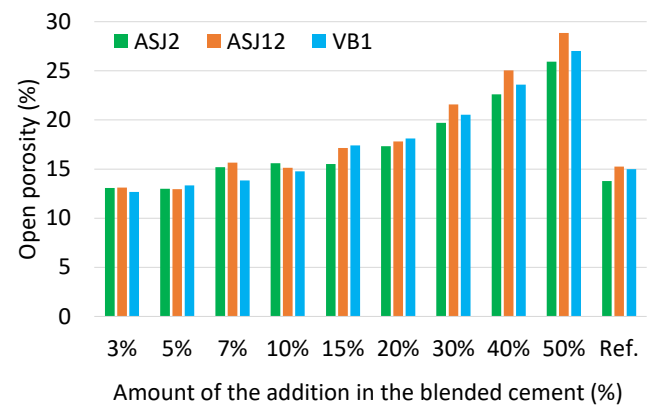

(c)

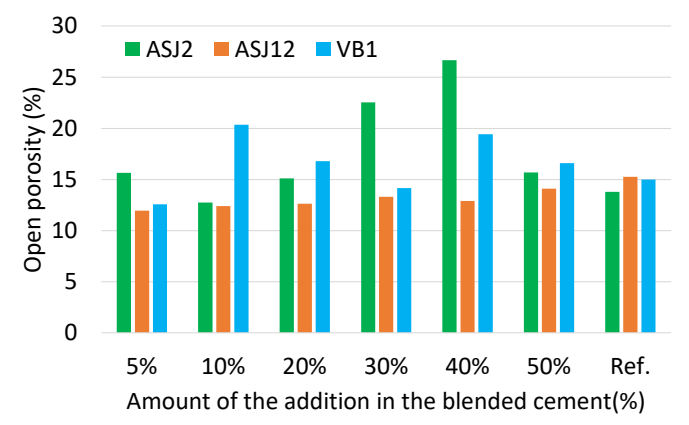

(b)

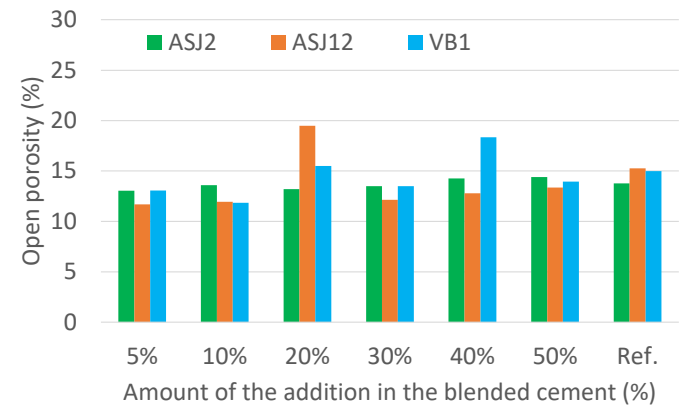

(d)

Figure 5. Open porosity results of the mortars made with the three aggregates and four additions added in four percentages of 20\%,30\%, 40\% and 50\%: (a) natural pozzolan, P; (b) siliceous coal fly ash, $\mathrm{V}$; (c) silica fume, D; (d) blast-furnace slag, $\mathrm{S}$.

It has been reported higher compressive strength in mortars with nano- $\mathrm{SiO}_{2}$ particles of $40 \mathrm{~nm}$ in size than with particles between 12 and $20 \mathrm{~nm}$ due to the agglomeration of the small particles [52]. Therefore, the resulting agglomerates will influence on the filling of the capillary pores [44]. Accordingly, nano- $\mathrm{SiO}_{2}$ particles in a range of $4-8 \%$ in mortars can promote an increase in the total porosity $[53,54]$.

\subsection{Alkali-Aggregate Mitigation by Pozzolanic Additions in Cement Mortars}

The alkali-aggregate test method prescribed by the Spanish standard UNE 146508 [33], which is equivalent to the American standard ASTM C-1260 [38] was selected to assess the ASR mitigation potential of natural pozzolan, $\mathrm{P}$, siliceous coal fly ash, V, silica fume, D, and blast-furnace slag, S, additions present in blended cements in the percentages shown in Table 1. This study was developed using mortars made with three aggregates (non-reactive siliceous sand, ASJ_2 (Figure 6); siliceous gravel with moderate reactivity, VB (Figure 7); and a reactive siliceous pebble, ASJ_12 (Figure 8). Mortar bar expansion measurements were taken from two until 90-days.

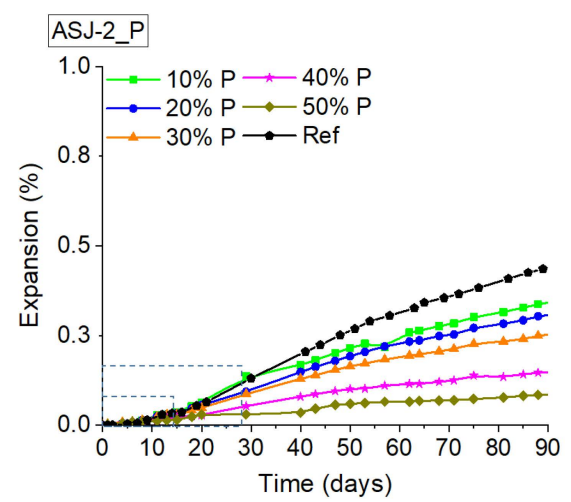

(a)

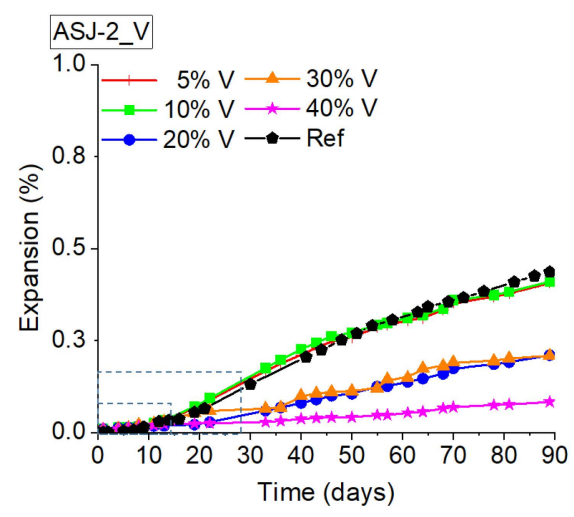

(b)

Figure 6. Cont. 


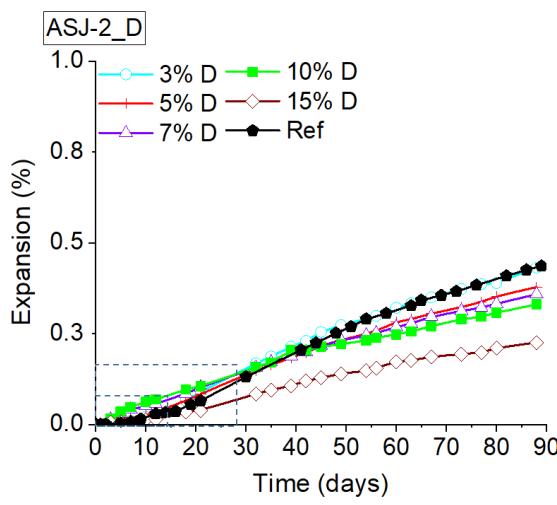

(c)

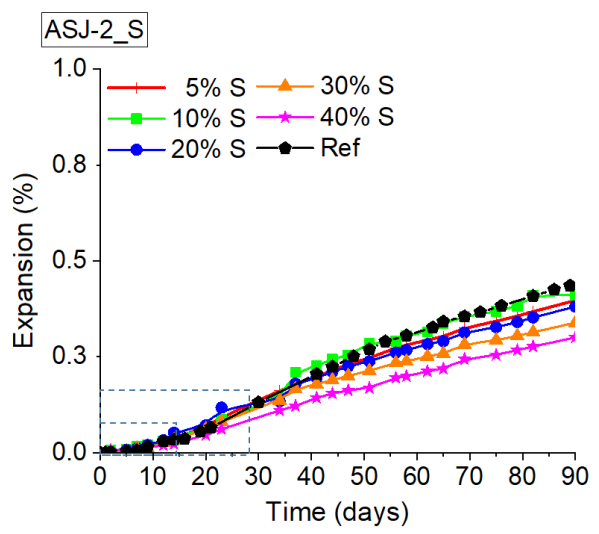

(d)

Figure 6. Alkali-silica mitigation by pozzolanic additions in mortars made with the non-reactive siliceous sand, ASJ_2, and four additions mixed in four percentages of $20 \%, 30 \%, 40 \%$ and $50 \%$ : (a) natural pozzolan, P; (b) siliceous coal fly ash, V; (c) silica fume, D; (d) blast-furnace slag, S.

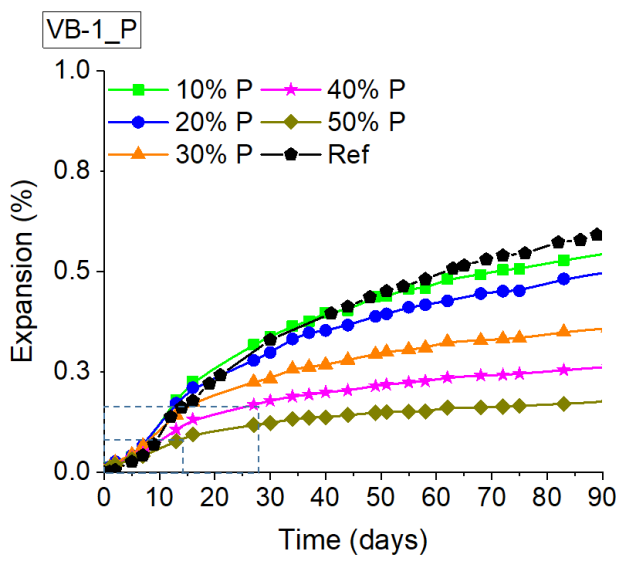

(a)

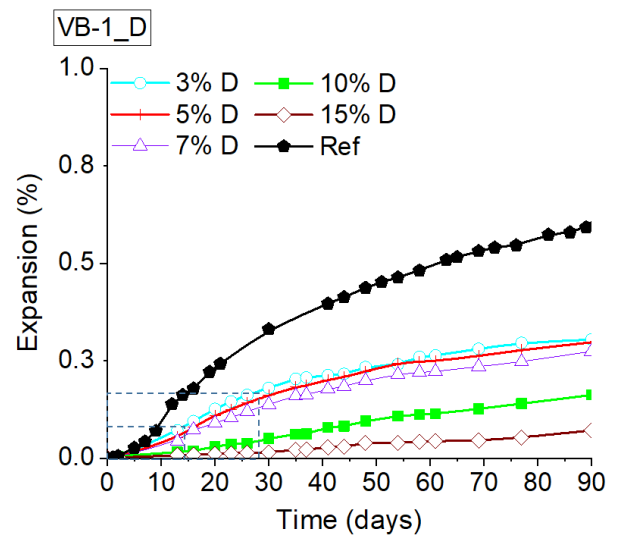

(c)

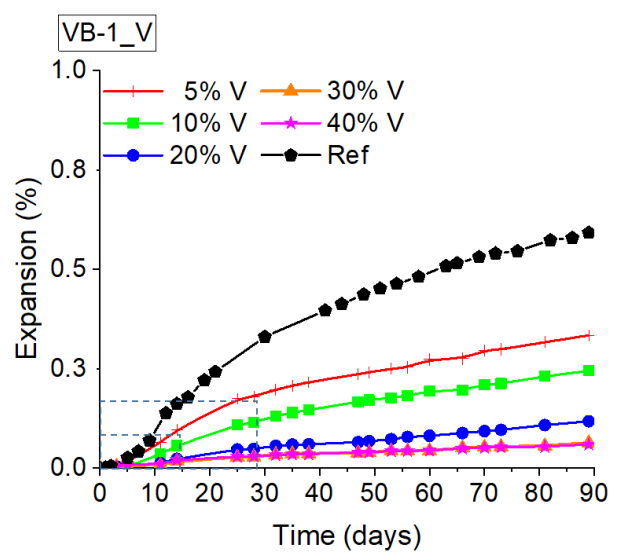

(b)

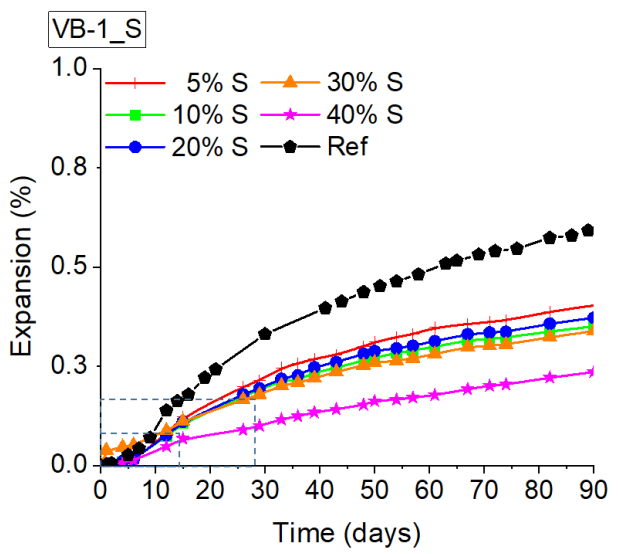

(d)

Figure 7. Alkali-silica mitigation by pozzolanic additions in mortars made with the siliceous gravel with moderate reactivity, VB, and four additions mixed in four percentages of $20 \%, 30 \%, 40 \%$ and $50 \%$ : (a) natural pozzolan, P; (b) siliceous coal fly ash, V; (c) silica fume, D; (d) blast-furnace slag, S. 


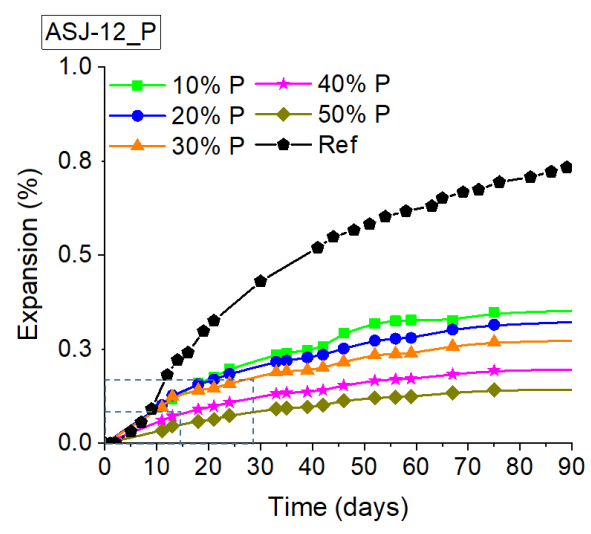

(a)

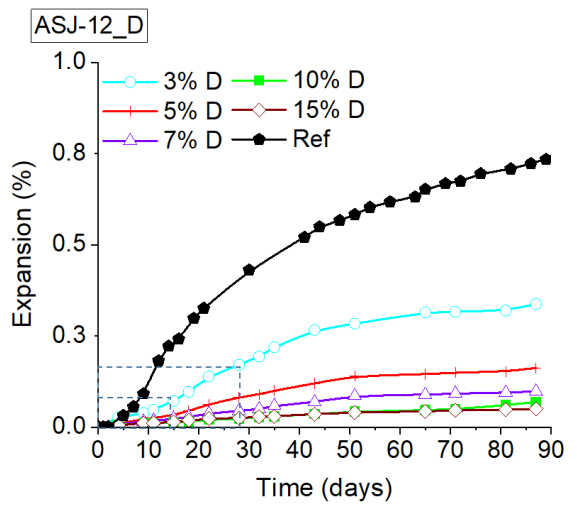

(c)

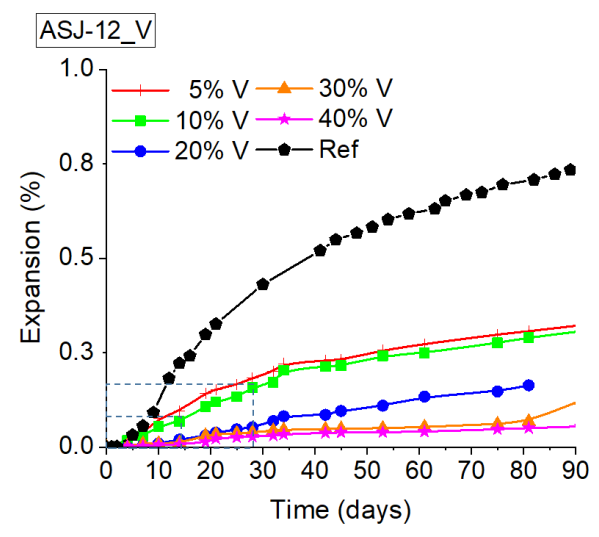

(b)

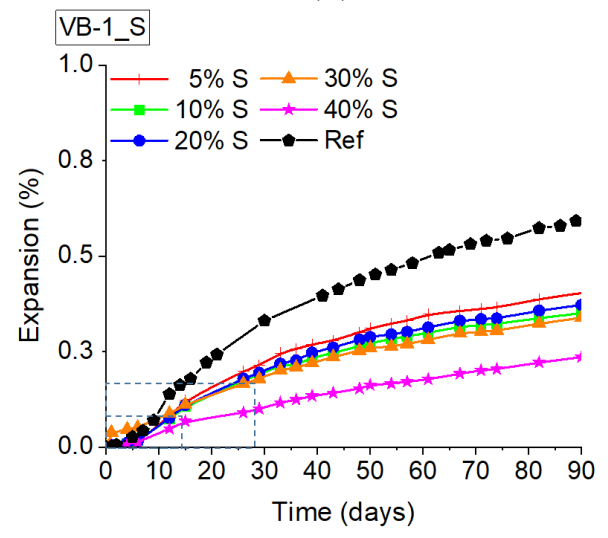

(d)

Figure 8. Alkali-silica mitigation by pozzolanic additions in mortars made with the reactive siliceous pebble, ASJ_12, and four additions mixed in four percentages of 20\%,30\%, 40\% and 50\%: (a) natural pozzolan, $\mathrm{P}$; (b) siliceous coal fly ash, V; (c) silica fume, D; (d) blast-furnace slag, S.

The average expansions, of three mortar bars for each pozzolanic material, for 90 days of exposure to $1 \mathrm{M} \mathrm{NaOH}$ at $80{ }^{\circ} \mathrm{C}$ are shown graphically in Figures 6-8. The mortar control specimen, with no partial replacement of cement, CEM I, by pozzolanic materials, showed that ASJ_2 was a non-reactive aggregate, VB was a moderate reactive aggregate and ASJ_12 was a highly reactive aggregate with an average expansion exposure of $0.22 \%$ after 14 days, which was more than the threshold level of $0.2 \%$ specified as reactive by UNE 146508 [33].

All the mortar samples with partial replacement of cement by the four pozzolanic materials showed improvement in the ASR performance in different levels with a general decrease in the average expansion measured in three samples. Considering each type of pozzolanic material employed in this study separately, the results evidenced that the higher partial replacement of cement with any of the four pozzolanic materials was effective in improving in ASR resistance. The average expansion of mortar bar results made with the moderate reactive aggregate and with different amount of natural pozzolan partially replacing cement were $\mathrm{V}<\mathrm{P}<\mathrm{D}<\mathrm{S}$ (Figure 7). This trend was also observed with the high reactive aggregate (Figure 8).

All the expansion results shown in Figure 6 fall in the area between the origin of the graph and the points $0.1 \%$ and 14 -days. Therefore, this (ASJ-2) is a non-reactive aggregate. The accelerated expansion mortar bar test was extended for 90 days to study the effect of the four pozzolanic materials. In the case of the blended cement mortars, it was clear the positive effect of the addition, i.e., the higher the pozzolanic material content in the mortar is, the higher the ASR mitigation is found. However, $5 \%$ or $10 \%$ of coal fly ash in the mix has no effect on the expansion evolution. The addition of $20 \%$ and $30 \% \mathrm{~V}$ presented a positive effect, while $40 \% \mathrm{~V}$ exhibited the best performance, i.e., mortar bar expansion below $0.1 \%$ at 90 days. Similarly, a content of $3 \%$ of silica fume in the mortar bar has no 
effect on the expansion, while amounts of $15 \%$ of silica fume presented expansions about $0.2 \%$ at 90 days. According to Bérubé and Duchesne [55], the long-term effectiveness of condensed silica fume mitigating the ASR is questioned because the alkali metals are entrapped quite soon in low $\mathrm{Ca} / \mathrm{Si}$ and high-alkali pozzolanic calcium silicate hydrates (for short C-S-H gel), and then, they are released with the time. Finally, blast-furnace slag had a positive effect but somewhat lower than $\mathrm{P}, \mathrm{V}$ or $\mathrm{D}$. This can be justified by the lower aluminum content found in the blast-furnace slag (12.16\% $\mathrm{Al}_{2} \mathrm{O}_{3}$ in Table 2).

The reference mortar made with high-reactive aggregate showed expansion results of $0.25 \%$ at 14 days and $0.42 \%$ at 28 days, which demonstrate the high reactivity of the siliceous pebble (Figure 8 ). In this case, the most effective additions mitigating the ASR were coal fly ash and silica fume.

A high content of coal fly ash $(20 \%, 30 \%$ or $40 \%$ V) suppresses the ASR effect. In agreement with Shehata and Thomas [27], coal fly ash with alkali content lower than $4 \% \mathrm{Na}_{2} \mathrm{O}_{\text {eq }}$ and calcium content lower than $20 \% \mathrm{CaO}$ was effective in mitigating expansion. They reported that higher amounts of $\mathrm{CaO}$ increase the concrete expansion. Coal fly ash consumes calcium hydroxide from pore solution lowering its alkalinity and forming $\mathrm{C}-\mathrm{S}-\mathrm{H}$ gel with low $\mathrm{Ca} / \mathrm{Si}$ ratio. In addition, this product reduces the capillary porosity. Accordingly, the expansions of mortar bars not only depend on the coal fly ash calcium content, but also on the $\mathrm{CaO} / \mathrm{SiO}_{2}$ ratio [27]. The higher $\mathrm{CaO} / \mathrm{SiO}_{2}$ ratio is, the higher expansion is expected.

Regarding the silica fume, amounts as low as $5-15 \%$ D were also found quite effective. Accordingly, the content of coal fly ash or silica fume needed to suppress ASR is dependent on the aggregate reactivity. Silica fume is one of the most efficient pozzolanic materials for reducing alkali-silica attack even when utilized at rather low replacement levels (10-15\%) by decreasing the $\mathrm{Na}^{+}, \mathrm{K}^{+}$and $\mathrm{OH}^{-}$ion concentrations in the pore solution of the cement-based material due to the alkali-binding capacity of C-S-H gel in hydrated Portland cement pastes with this pozzolanic addition [56].

The pozzolanic reaction rate of silica fume is higher than that of coal fly ash, natural pozzolan and blast-furnace slag due to its higher fineness and reactive silicon dioxide. However, the long-term effectiveness of condensed silica fume against ASR is questioned in the literature [55]. Silica fume binds alkali ions within the first two days of hydration following a similar rection to that of the alkali-silica reaction [27]. ASR gel located on the silica surface reacts with calcium to form C-S-H gel with a low $\mathrm{Ca} / \mathrm{Si}$ ratio. Accordingly, most alkali metals are fixed by the silica fume particles and the $\mathrm{C}-\mathrm{S}-\mathrm{H}$ gel formed in the hydration of calcium silicate paste. At a more advanced age, ASR gel will react with calcium leading to release of $\mathrm{Na}^{+}$and $\mathrm{K}^{+}$into the pore solution. Therefore, they become available for ASR and the alkalinity of the pore solution increases throughout time, i.e., months or years [27].

Accelerated mortar bar expansion measurements have been extended to three months to detect mentioned increased alkali level over time. Nevertheless, one disadvantage in carrying out these trials is the reduction of the alkali level in the mortar pore solution by leaching.

High amounts of $\mathrm{P}(40 \%$ and $50 \%)$ or S $(20 \%, 30 \%$ and $40 \%)$ resulted also effective. In order to ensure a positive effect on ASR mitigation, the blended cement normally needs a large volume of clinker replacement by blast-furnace slag. In some cases, this content should be above $50 \%$ [25] or $60 \%$ [57]. The lowest effectivity of blast-furnace slag could be attributed to its less content of aluminum. Aluminosilicate pozzolanic materials such as $\mathrm{P}, \mathrm{V}$ and $\mathrm{S}$ have the capacity of suppressing the deleterious effects of ASR. The amount which must be added for a given reactive aggregate can only be determined by testing, whose long-term trustworthily is frequently questioned.

It is well-known that pozzolanic materials lower the $\mathrm{pH}$ of the cement-based material pore solution. This fact promotes the change in composition of calcium silicate hydrate, $\mathrm{C}-\mathrm{S}-\mathrm{H}$ gel, which is the main binding phase in mentioned cement-based materials. Nevertheless, it has been suggested that pozzolanic materials containing alumina such as coal fly ash are more effective in reducing ASR than those containing only silica [26]. It has been observed that the incorporation of alumina in C-S-H gel does not lower the $\mathrm{pH}$ of the pore solution significantly. In addition, reactive aggregates kept in alkaline solutions with alumina deteriorate less than those kept in similar solutions with no alumina [58]. ASR gel formation depends on the rate of rupture of siloxane bonds, i.e., dissolution of amorphous 
silica [59]. Hydroxyl ions break up the $\mathrm{Si}-\mathrm{O}-\mathrm{Si}$ bonds and negative charges are formed, which later are neutralized by alkalis. This physicochemical process opens the silica microstructure and water penetrates the gel. The dissolution kinetics involved in this process depend on the composition of the pore solution, temperature, and interfacial free energy [60].

The effect of aluminum containing constituent on the amorphous silica dissolution has been widely discussed in the literature [22,61]. It seems that aluminum is incorporated, as $\mathrm{AlO}_{4}$ tetrahedra, into $\mathrm{SiO}_{4}$ tetrahedral sites on the silica framework, not just surface adsorbed. However, a thin layer is enough to significantly reduce amorphous silica dissolution [61]. Furthermore, it has been demonstrated the effect of aluminum on reducing quartz dissolution in the high alkalinities found in cement paste. Nevertheless, the reduction in the dissolution rate of amorphous silica due to the presence of aluminum decreases as the $\mathrm{pH}$ increased [62] and the positive effect on the ASR is almost the same irrespective of the aluminum concentration in the pore solution [53] because the aluminum incorporation level is independent of such concentration.

Regarding the reference mortar made with the moderate reactive aggregate, it presented an intermediate expansion result between the reference mortar made with the non-reactive aggregate and the high-reactive one (Figure 7). Then, the mitigating effect of the pozzolanic materials was much lower than that found in high-reactive aggregate mortar. This can be explained by the synergetic effect proposed here between the formed ASR gel and the pozzolanic reaction involved in this physicochemical process. Coal fly ash and silica fume are again the most efficient additions in suppressing ASR. However, only high contents of natural pozzolan $(40 \%$ and $50 \%)$ or blast-furnace slag $(40 \%)$ could be considered quite effective in mitigating ASR in mortars with moderate reactivity aggregates.

ASR mitigation degree of natural pozzolan, $\mathrm{P}$, siliceous coal fly ash, $\mathrm{V}$, silica fume, $\mathrm{D}$, and blast-furnace slag, $\mathrm{S}$, additions (from 3\% to $50 \%$ of content in the blended cement according to Table 2) was assessed with three kinds of aggregates with different reactivity: ASJ_12 (high-reactive) $>$ VB > ASJ_2 (non-reactive). The aim is to get the most adequate type of addition and percentage for each aggregate to suppress the ASR. Figure 9 shows a comparison of the effectiveness for the mortars made with three aggregates (non-reactive siliceous sand, ASJ_2; siliceous gravel with moderate reactivity, VB; and a reactive siliceous pebble, ASJ_12). ASR mitigation was assessed by means of Equation (3), where the expansion recorded in mortars with the pozzolanic material (blended mortar expansion) is compared with the expansion monitored in mortars made with cement without any addition (CEM I mortar expansion):

$$
\text { ASR mitigation }(\%)=\frac{\text { CEM I mortar expansion }- \text { Blended mortar expansion }}{\text { CEM I mortar expansion }} \times 100
$$

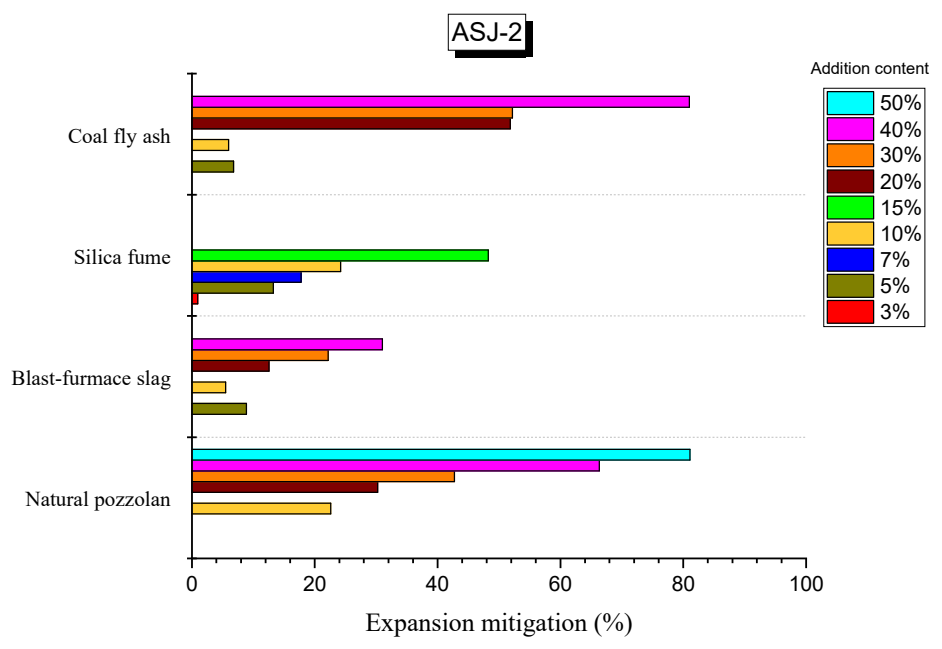

(a)

Figure 9. Cont. 


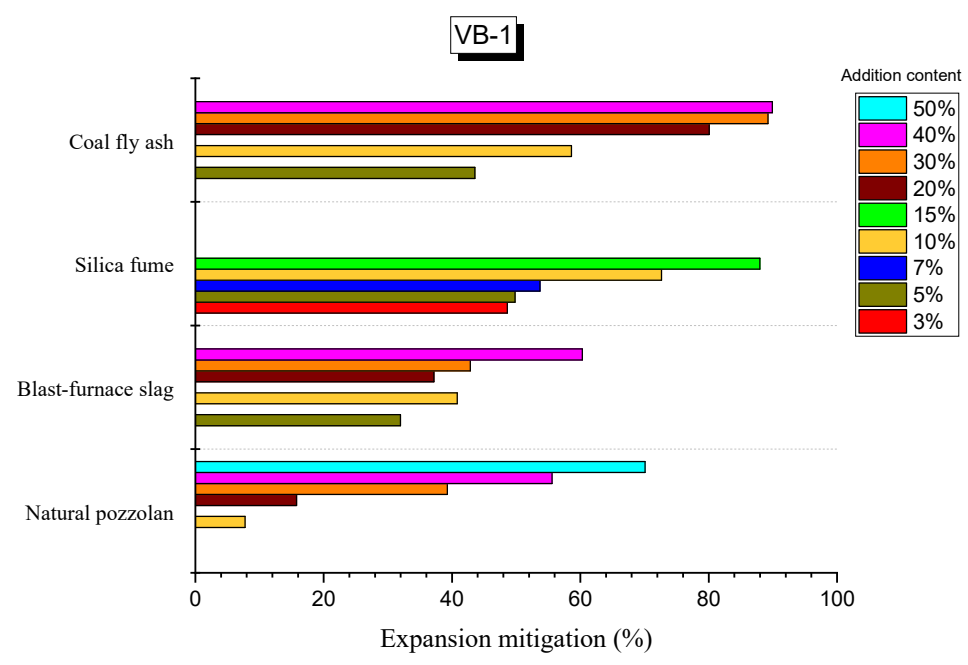

(b)

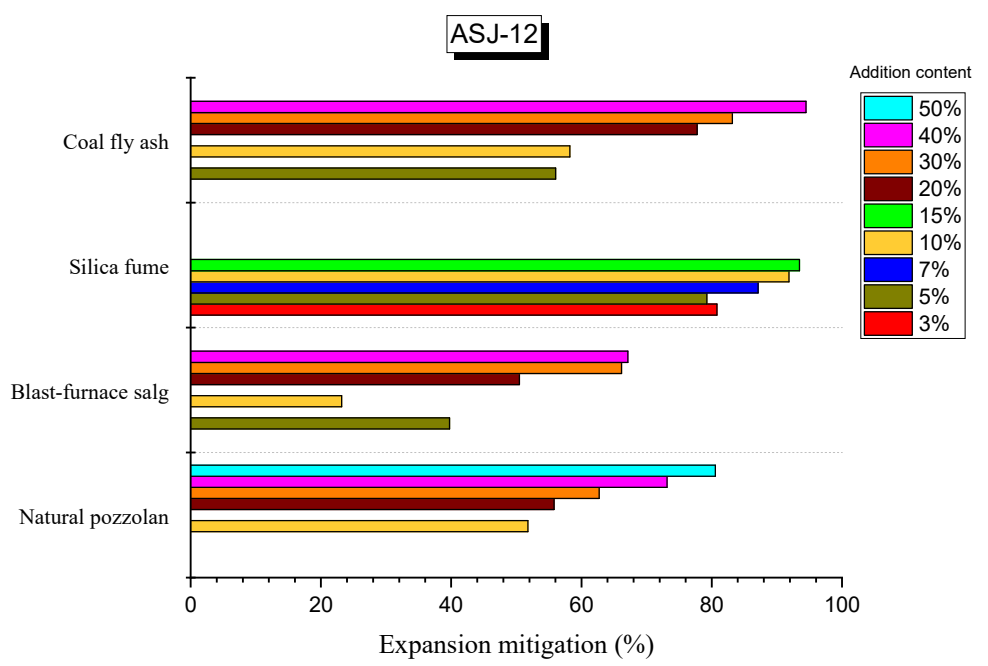

(c)

Figure 9. Alkali-silica mitigation by four pozzolanic additions in percentages from $3 \%$ to $50 \%$ in mortars made with three aggregates: (a) non-reactive siliceous sand, ASJ_2; (b) siliceous gravel with moderate reactivity, VB; (c) reactive siliceous pebble, ASJ_12.

Reactivity of natural pozzolans is mainly based on the amounts of active constituents, primarily reactive silica, which is part of the total silica of silica fume. Reactive silica reacts with calcium hydroxide (for short $\mathrm{CH}$ ) produced from Portland cement hydration and forms calcium silicate hydrates (for short $\mathrm{C}-\mathrm{S}-\mathrm{H}$ gel) with lower $\mathrm{Ca} / \mathrm{Si}$ ratio than the $\mathrm{C}-\mathrm{S}-\mathrm{H}$ gel formed during the Portland cement hydration. Both of them provide binding and strengthening properties to the cement. Then, silica fume has a twofold role in the cementitious system: it will play both a chemical role (pozzolanic reaction), and also, a physical one (filler function) [45]. Nevertheless, small silica fume particles enhance higher water demand that could reduce the cement-based material workability [46].

With regard to the alumina content present in blended cements with coal fly ash, blast-furnace slag or natural pozzolans, it is believed that is ineffective to mitigate ASR expansion probably due to the expansive ettringite formation replacing calcium monosulphate in the pore solution [63]. However, coal fly ash with a high amount of alumina has higher alkali binding capacity than low alumina coal fly ash and leads to C-S-H-A gel formation [29]. The coal fly ash used in the present work has $23 \%$ $\mathrm{Al}_{2} \mathrm{O}_{3}$. Then, high alumina coal fly ash replacements of $20-40 \%$ are useful to reduce ASR expansion. Furthermore, coal fly ash cement pastes reduce permeability by pozzolanic reaction and filler effect. 
These two processes reduce the capillary pores formation and avoid the ASR gel accumulation on the reactive aggregates. The pozzolanic reaction consumes calcium hydroxide from the pore solution promoting the alkalinity reduction. In addition, coal fly ash modifies the alkali-silica gel properties, i.e., reduce the ASR gel viscosity and the swelling pressure $[64,65]$. Therefore, coal fly ash blended cements mitigate ASR attack in agreement with the literature $[19,22,27,57,65]$. The coal fly ash effectiveness depends on the calcium content and on the calcium oxide to silica ratio [27].

Figure 9a represents the ASR mitigation results in mortars with a low expansion. In this case, only high amount of coal fly ash $(20 \%, 30 \%$ and $40 \%)$ and natural pozzolan $(40 \%$ and $50 \%)$ in the mortar reduce the expansion level from $50 \%$ to $80 \%$.

As shown in Figure 9b, the mitigation degree is higher in mortars made with moderate-reactive aggregates, i.e., about $90 \%$ for silica fume ( $15 \%$ D) and coal fly ash ( $30 \%$ and $40 \%$ V). Furthermore, high contents of blast-furnace slag and natural pozzolan (>40\%) also achieved mitigation degrees over $50 \%$. Nevertheless, the highest mitigation level was found in mortars with high-reactive aggregates.

Finally, mitigation degree in blended cement mortars made with the high-reactive aggregates exhibited the best ASR mitigation performance (Figure 9c). Coal fly ash $(40 \% \mathrm{~V})$ reached more than $95 \%$ of efficiency, whereas silica fume reached nearly $95 \%(10-15 \% \mathrm{D})$, natural pozzolan reached over $75 \%(40-50 \% \mathrm{P})$ and blast-furnace slag over $60 \%(30-40 \% \mathrm{~S})$.

\subsection{Microanalysis of Pozzolanic Cement Mortars}

Following the 90-days accelerated mortar bar test expansion measurement, mortar prisms were kept in a plastic container with a $1 \mathrm{~N} \mathrm{NaOH}$ solution for 30 months. Afterwards, they were for examination of mortar specimens, made with two reactive aggregates and a non-reactive one, by scanning electron microscopy (SEM) using backscattered electron imaging contrast (Figure 10).

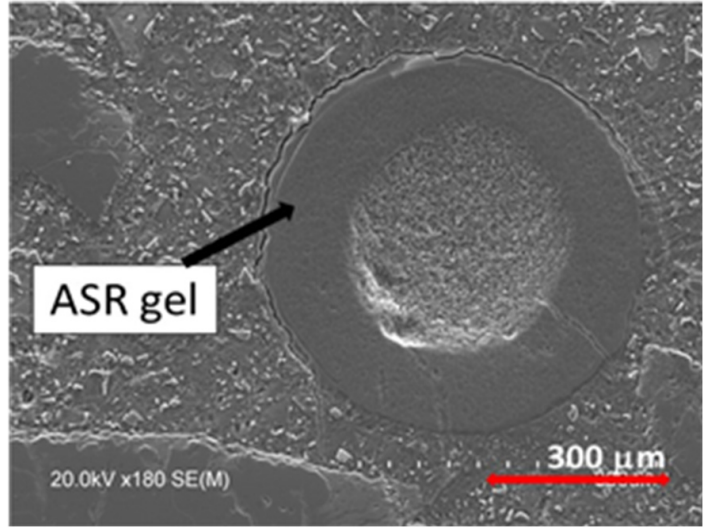

(a)

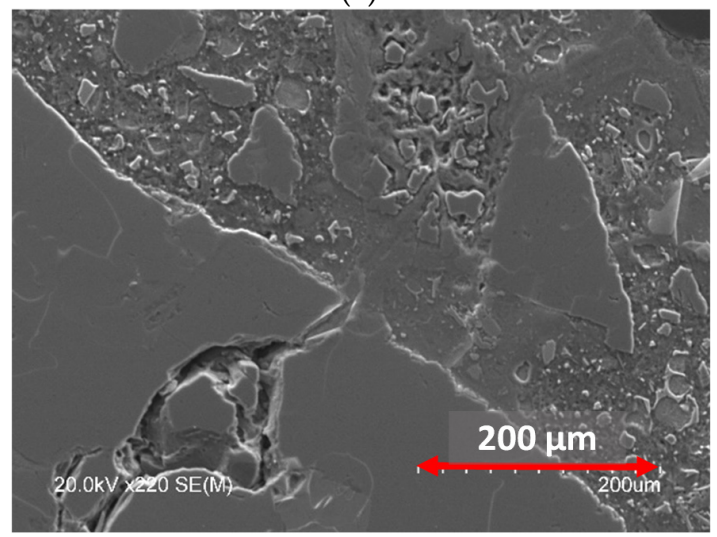

(c)

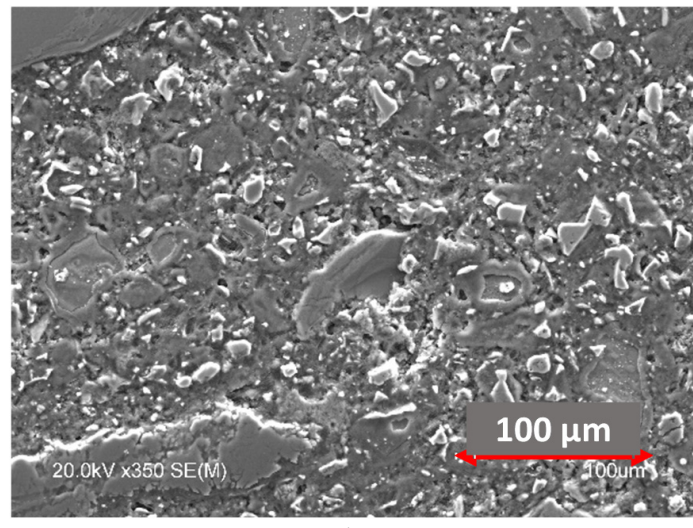

(b)

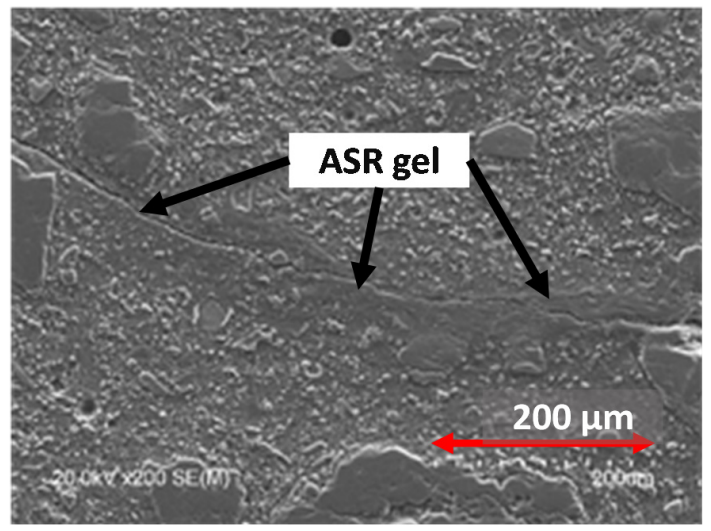

(d)

Figure 10. Cont. 


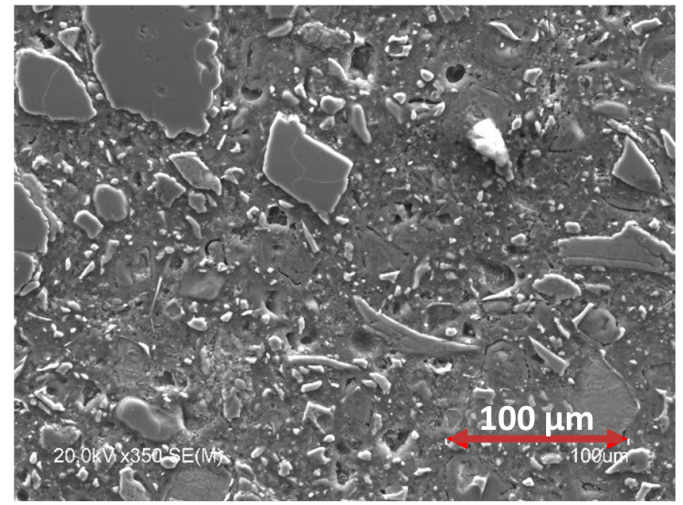

(e)

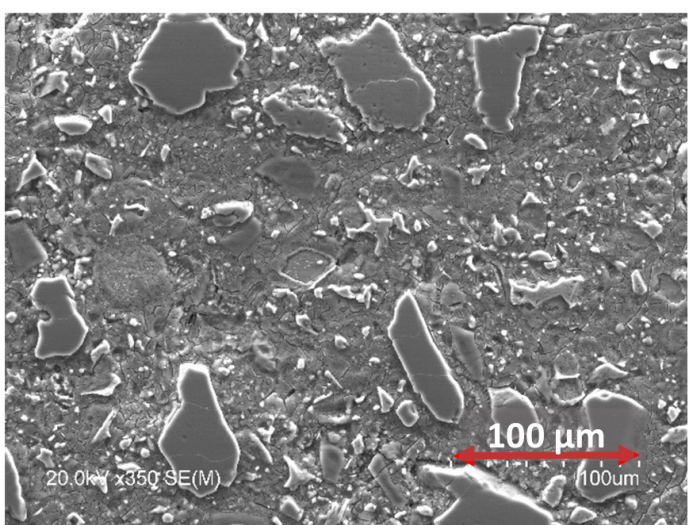

$(\mathbf{f})$

Figure 10. Backscattered SEM image of mortars made with the high-reactive siliceous pebble, ASJ_12 after 90 days of testing and subsequent preservation in a $1 \mathrm{~N} \mathrm{NaOH}$ solution for 30 months: (a) reference mortar; (b) reference mortar; (c) mortar with $10 \%$ of natural pozzolan; (d) mortar with $10 \%$ of siliceous coal fly ash; (e) mortar with $10 \%$ of silica fume; (f) mortar with $10 \%$ of blast-furnace slag.

Corresponding to its high expansion, widespread cracking was observed using an SEM in the microstructure of the mortar control sample. The blended cement mortars exhibited lower or non-cracking when examined after 90-days of expansion testing and subsequent preservation in a $1 \mathrm{~N}$ $\mathrm{NaOH}$ solution for 30 months. Several typical micrographs from mortars made without additions and with natural pozzolan, $\mathrm{P}$, siliceous coal fly ash, $\mathrm{V}$, silica fume, $\mathrm{D}$, and blast-furnace slag, $\mathrm{S}$, are shown in Figure 10.

The reference mortar shows some cracks and pores filled with ASR gel. In addition, the mortar made with cement containing $10 \%$ of coal fly ash, V, also presents some cracks. Generally, cracks are filled with ASR gel. Cracks up to $10 \mu \mathrm{m}$ wide were observed at the interface or within reacted aggregates in mortars. On the other hand, mortar elaborated with cement containing $10 \%$ of blast-furnace slag, S, or $10 \%$ of silica fume or $10 \%$ of natural pozzolan showed a cohesive aspect without any visible alteration.

Figures 11 and 12 show the composition of $\mathrm{C}-\mathrm{S}-\mathrm{H}$ gel in cement paste contained in the mortars at 30 months obtained by energy dispersive $X$-ray (EDX). The diagrams represent $\left(\left[10 \cdot\left(\mathrm{Na}_{2} \mathrm{O}_{\text {eq }}\right)+\right.\right.$ 4.45. $\mathrm{CaO}] / \mathrm{SiO}_{2}$ ) against the expansion and the $\mathrm{Si} / \mathrm{Ca}$ ratio against the $\mathrm{Al} / \mathrm{Ca}$ ratio, respectively. The expansion is a linear function of $\left(\left[10 \cdot\left(\mathrm{Na}_{2} \mathrm{O}_{\text {eq }}\right)+4.45 \cdot \mathrm{CaO}\right] / \mathrm{SiO}_{2}\right)$ in the case of natural pozzolans. However, the expansion is independent such relation. With regard to the mortars made with coal fly ash and silica fume, no clear relationship has been found between the expansion and ([10. $\left(\mathrm{Na}_{2} \mathrm{O}_{\text {eq }}\right)+$ $\left.4.45 \cdot \mathrm{CaO}] / \mathrm{SiO}_{2}\right)$.

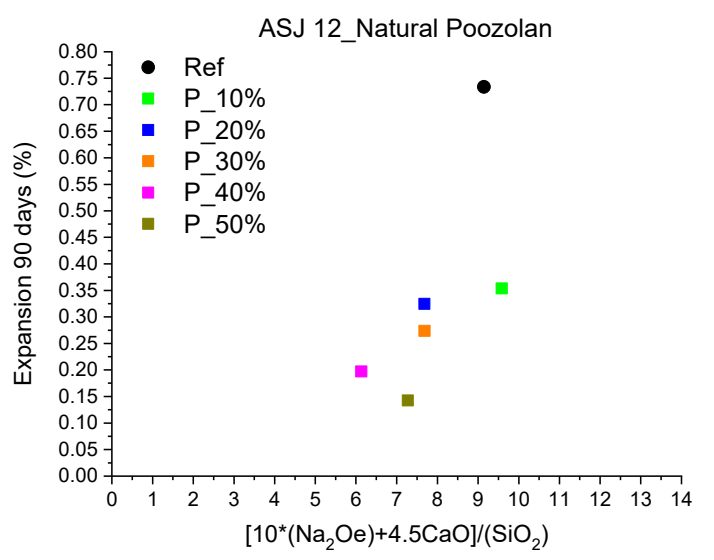

(a)

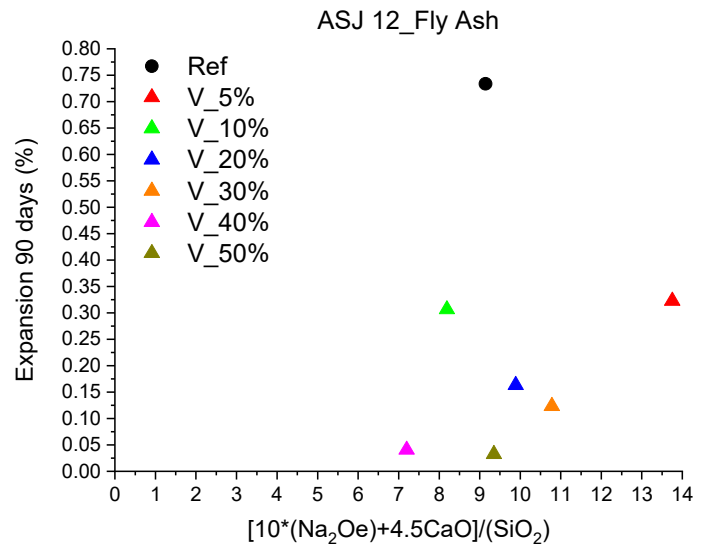

(b)

Figure 11. Cont. 


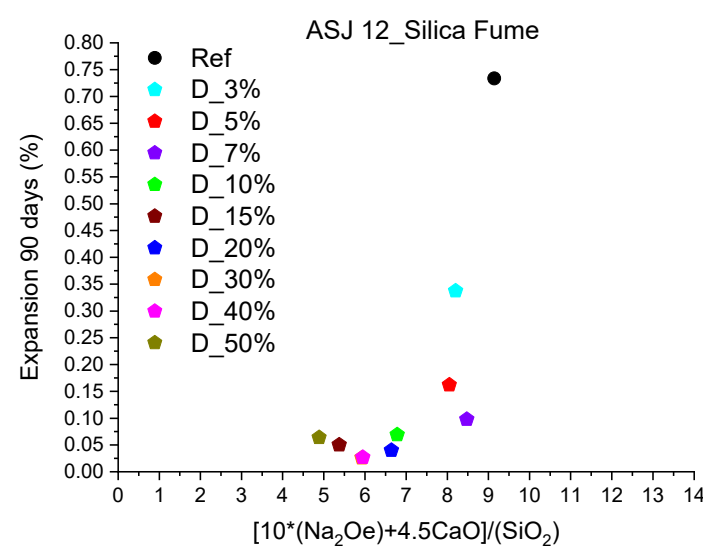

(c)

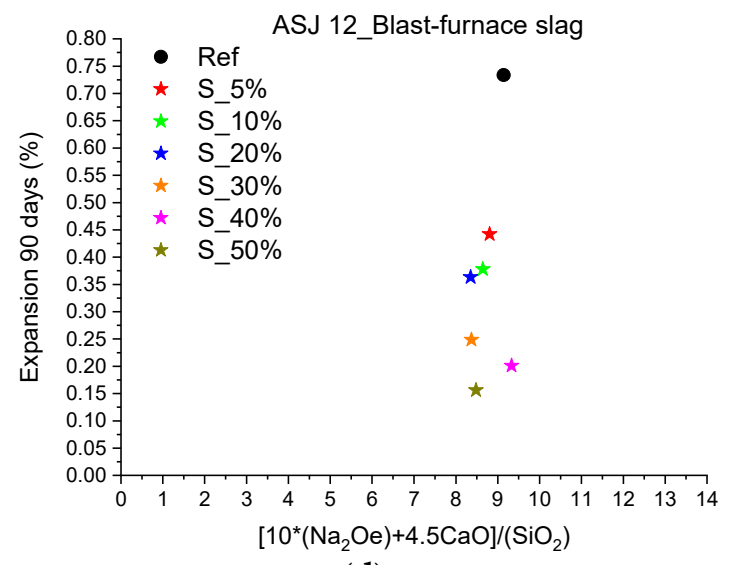

(d)

Figure 11. Relation between $\left(\left[10 \cdot\left(\mathrm{Na}_{2} \mathrm{O}_{\mathrm{eq}}\right)+4.45 \cdot \mathrm{CaO}\right] / \mathrm{SiO}_{2}\right)$ and expansion of mortars made with the high-reactive siliceous pebble, ASJ_12, and four additions mixed in different percentages after 90 days of testing: (a) natural pozzolan, P; (b) siliceous coal fly ash, V; (c) silica fume, D; (d) blast-furnace slag, S.

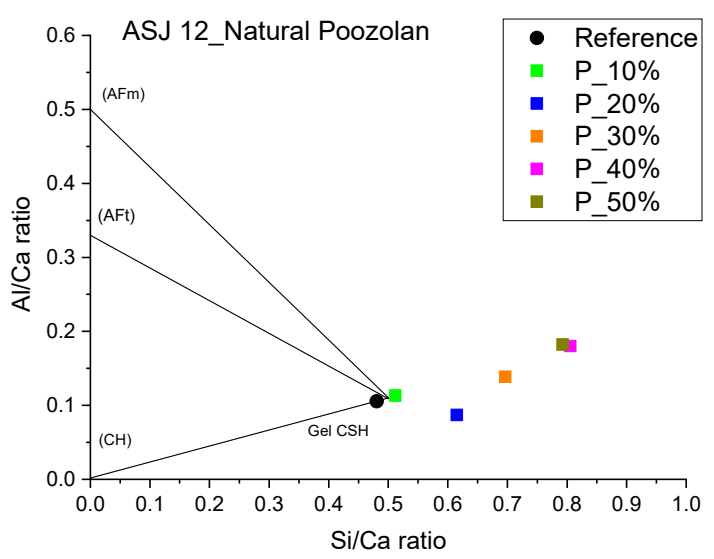

(a)

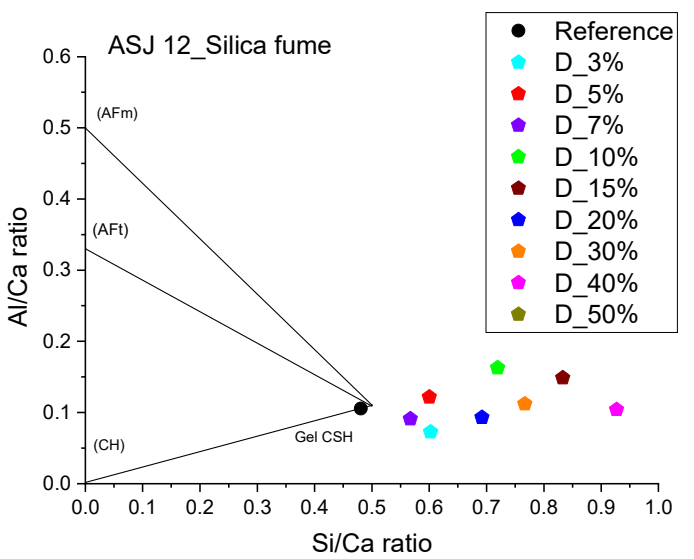

(c)

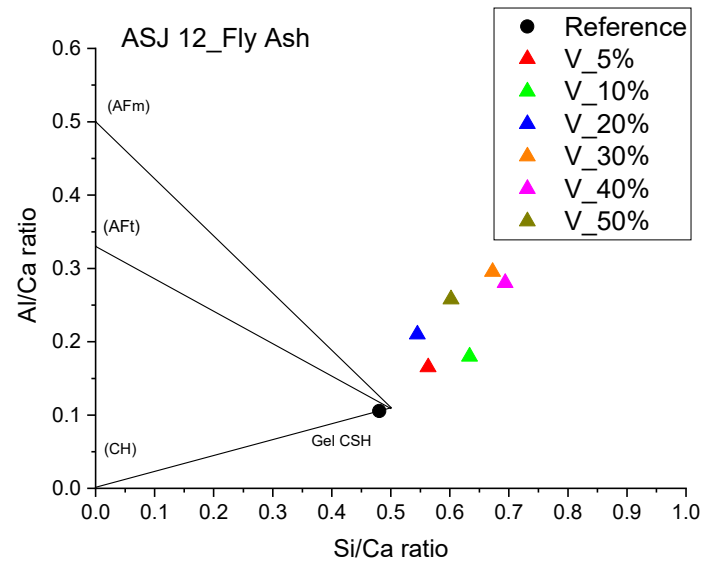

(b)

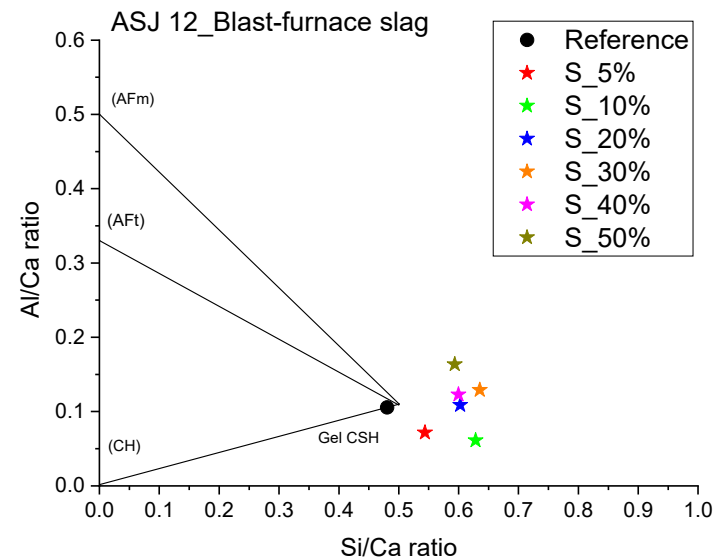

(d)

Figure 12. Relation between the $\mathrm{Si} / \mathrm{Ca}$ ratio and the $\mathrm{Al} / \mathrm{Ca}$ ratio of mortars made with the high-reactive siliceous pebble, ASJ_12, and four additions mixed in different percentages after 90 days of testing: (a) natural pozzolan, $\mathrm{P}$; (b) siliceous coal fly ash, V; (c) silica fume, D; (d) blast-furnace slag, S.

It is noted that the composition of $\mathrm{C}-\mathrm{S}-\mathrm{H}$ gel has a $\mathrm{Si} / \mathrm{Ca}$ ratio ranging from 0.5 to 0.95 . In particular, the values of $\mathrm{Si} / \mathrm{Ca}$ ratio for the natural pozzolan pastes range from 0.5 to 0.8 , for the fly ash pastes from 0.6 to 0.7 and for blast-furnace slag pastes from 0.55 to 0.65 . Conversely, pastes with silica fume have much higher ratios, up 0.95 . This is due to the high $\mathrm{Ca}(\mathrm{OH})_{2}$ consumption during the pozzolanic 
reaction between the reactive silica present in the silica fume and the calcium hydroxide, which was formed during the hydration reaction of the Portland cement.

With respect to the $\mathrm{Al} / \mathrm{Ca}$ ratio, the values range from 0.05 to 0.3 . A direct relationship was found between $\mathrm{Al} / \mathrm{Ca}$ ratio and the addition content in the first three cases (natural pozzolan, silica fume and fly ash pastes). Surprisingly, virtually no relationship was found for blast-furnace slag pastes.

The reference cement has an $\mathrm{Al} / \mathrm{Ca}$ ratio of about 0.1. The values of $\mathrm{Al} / \mathrm{Ca}$ ratio for the natural pozzolan pastes range from 0.1 to 0.2 , for the fly ash pastes from 0.15 to 0.3 , for the silica fume pastes range from 0.05 to 0.15 and for blast-furnace slag pastes from 0.05 to 0.2. As expected, the $\mathrm{Al}$ amount in the $\mathrm{C}-\mathrm{S}-\mathrm{H}$ gel increases with the fly ash proportion in the cement.

The effect of coal fly ash on alkali-silica reaction expansion can be attributed to the reduction of available alkalis in the pore solution and to the $\mathrm{C}-\mathrm{S}-\mathrm{H}$ gel capacity to incorporate alkalis into its structure.

In general, the pozzolanic materials are able to lower the alkalinity of the pore solution. Their efficiency depends on their chemical composition themselves. For instance, such efficiency is related to the low calcium and alkali contents and high silica amount of coal fly ash. Accordingly, Class F fly ash is more effective than Class $\mathrm{C}$ fly ash in preventing alkali-aggregate reaction due to its chemical composition [27,57].

\section{Conclusions}

The conclusions extracted from this research work are as follows: (1) Blended cements made with natural pozzolan, $\mathrm{P}$, siliceous coal fly ash, V, silica fume, D, and blast-furnace slag, $\mathrm{S}$ were found to be effective in alleviating ASR expansion in mortar bars; (2) The more reactivity of the aggregate is, the higher ASR mitigation level was found in blended cements; (3) The best additions with regard to the ASR inhibition are the silica fume and the siliceous fly ash; (4) The higher addition contents provide improved ASR inhibition performances, however, mechanical properties are negatively affected at the same time. Regarding the compressive strength evolution, coal fly ash and natural pozzolan additions in blended cements do not affect positively in any case. Nevertheless, ground granulated blast-furnace slag has a positive effect in mortars made with reactive aggregates. This seems to be a synergic effect between the ASR products and the blast-furnace slag. Finally, low silica fume contents (3-10\%) enhance the mechanical strength at early ages, whereas higher levels have a negative influence in this characteristic. The traditional way of explaining the compressive strength evolution via open porosity measurements no longer serve in cement-based materials made with reactive aggregates because the microstructure has changed in these cases not only by the effect of the additive, but also by the influence of the ASR reaction.

The best mix design to mitigate the ASR reaction should consider both the ASR inhibition and the mechanical performance. Accordingly, two main groups can be distinguished: (i) mixtures providing a large ASR reduction but also a significant compressive strength reduction and (ii) mixes with a moderate ASR inhibition and a compressive strength results broadly similar to those of the reference sample. The results of this work package have been taken into careful consideration in the development of the following proposal. The blended cements recommended to be used to mitigate the ASR reaction should contain high amounts of siliceous coal fly ash, natural pozzolan, silica fume, or blast-furnace slag. In this study, V was the most effective in suppressing ASR followed by D, P and S, respectively. It is believed that this depends partly on the different amount of alumina and silica present in these pozzolanic materials and their reactivity. In addition, the more cement replaced with pozzolanic materials, the higher the drawdown in expansion due to ASR.

Finally, it is suggested that decreasing the $\mathrm{Ca} / \mathrm{Si}$ ratio, the ASR expansion is reduced as there is less dissolution of silica. This is due to the lower availability of calcium to enhance the dissolution of silica and to the higher amount of aluminum available to hinder mentioned dissolution. 
Author Contributions: Conceptualization, E.M., R.G.-R. and M.Á.S.; methodology, E.M., R.G.-R. and M.Á.S.; validation, H.R., E.M., R.G.-R., M.Á.S. and C.A.; investigation, H.R., E.M., R.G.-R., M.Á.S. and C.A.; resources, E.M.; data curation, E.M., R.G.-R., M.Á.S. and C.A.; writing-original draft preparation, M.Á.S.; writing一review and editing, E.M., H.R., R.G.-R., M.Á.S. and C.A. All authors have read and agreed to the published version of the manuscript.

Funding: This research was funded by the CSIC (Intramurales Projects PIE 201660E054 y PIE 202060E176).

Acknowledgments: Authors gratefully acknowledge the valuable contributions of Beatriz Aldea and Esther Puerto.

Conflicts of Interest: The authors declare no conflict of interest.

\section{References}

1. European Commission, UE 2020. A New Industrial Strategy for Europe; Communication from the Commission to the European Parliament, The European Council, The Council, The European Economic, Social Committee and The Committee of the Regions; European Commission: Brussels, Belgium, 10 March 2020; Available online: https://ec.europa.eu/info/sites/info/files/communication-eu-industrial-strategy-march-2020_en.pdf (accessed on 16 October 2020).

2. European Commission, UE 2019. The European Green Deal; Communication from the Commission to the European Parliament, The European Council, the Council, The European Economic, Social Committee and The Committee of the Regions; European Commission: Brussels, Belgium, 11 December 2019; Available online: https://ec.europa.eu/info/sites/info/files/european-green-deal-communication_en.pdf (accessed on 16 October 2020).

3. European Commission, UE 2011. Roadmap to a Resource Efficient Europe; Communication from the Commission to The European Parliament, The Council, The European Economic and Social Committee and The Committee of the Regions; European Commission: Brussels, Belgium, 20 September 2011; Available online: https://eur-lex.europa.eu/legal-content/EN/TXT/PDF/?uri=CELEX:52011DC0571\&from=EN (accessed on 7 December 2020).

4. European Commission, UE 2017. The Role of Waste-to-Energy in the Circular Economy; Communication from The Commission to The European Parliament, The Council, the European Economic and Social Committee and The Committee of the Regions; European Commission: Brussels, Belgium, 26 January 2017; Available online: https://eur-lex.europa.eu/legal-content/EN/TXT/PDF/?uri=CELEX:52017DC0034\&from=en (accessed on 7 December 2020).

5. The European Parliament and The Council of the European Union, UE 2018. Directive (EU) 2018/2001 of the European Parliament and of the Council of 11 December 2018 on the Promotion of the Use of Energy from Renewable Sources. Available online: https://eur-lex.europa.eu/legal-content/EN/TXT/PDF/?uri=CELEX: 32018L2001\&from $=$ fr (accessed on 7 December 2020).

6. The European Parliament and The Council of the European Union, UE 2019. Regulation (EU) 2020/852 of the European Parliament and of the Council of 18 June 2020 on the Establishment of a Framework to Facilitate Sustainable Investment and Amending Regulation (EU) 2019/2088. Available online: https://eur-lex.europa.eu/legal-content/ EN/TXT/PDF/?uri=CELEX:32020R0852\&from=EN (accessed on 7 December 2020).

7. Holubčík, M.; Klačková, I.; Ďurčanský, P. Pyrolysis Conversion of Polymer Wastes to Noble Fuels in Conditions of the Slovak Republic. Energies 2020, 13, 4849. [CrossRef]

8. Sanjuán, M.A.; Argiz, C.; Mora, P.; Zaragoza, A. Carbon Dioxide Uptake in the Roadmap 2050 of the Spanish Cement Industry. Energies 2020, 13, 3452. [CrossRef]

9. European Commission, UE 2020. Circular Economy Action Plan. For a Cleaner and More Competitive Europe \#EUGreenDeal, 1st ed.; European Commission: Brussels, Belgium, 11 March 2020; pp. 1-28. Available online: https://ec.europa.eu/commission/presscorner/detail/en/ip_20_420 (accessed on 16 October 2020).

10. Sanjuán, M.Á.; Menéndez, E.; Argiz; Moragues, A. Coal bottom ash research program focused to evaluate a potential Portland cement constituent. In Proceedings of the Second International Conference on Concrete Sustainability, ICCS16, Madrid, Spain, 13-15 June 2016, 1st ed.; International Centre for Numerical Methods in Engineering (CIMNE): Madrid, Spain, 2016; pp. 532-543.

11. Sanjuán, M.Á.; Andrade, C.; Mora, P.; Zaragoza, A. Carbon Dioxide Uptake by Cement-Based Materials: A Spanish Case Study. Appl. Sci. 2020, 10, 339. [CrossRef] 
12. Soltangharaei, V.; Anay, R.; Hayes, N.W.; Assi, L.; Le Pape, Y.; Ma, Z.J.; Ziehl, P. Damage Mechanism Evaluation of Large-Scale Concrete Structures Affected by Alkali-Silica Reaction Using Acoustic Emission. Appl. Sci. 2018, 8, 2148. [CrossRef]

13. Petrounias, P.; Giannakopoulou, P.P.; Rogkala, A.; Stamatis, P.M.; Lampropoulou, P.; Tsikouras, B.; Hatzipanagiotou, K. The Effect of Petrographic Characteristics and Physico-Mechanical Properties of Aggregates on the Quality of Concrete. Minerals 2018, 8, 577. [CrossRef]

14. Menéndez, E. Comprehensive Strategy for the Prevention of the Alkali-Silica Reaction. 2019. Available online: https://digital.csic.es/handle/10261/211145 (accessed on 16 October 2020). (In Spanish).

15. Shin, J.-H.; Struble, L.J.; Kirkpatrick, R.J. Microstructural Changes Due to Alkali-Silica Reaction during Standard Mortar Test. Materials 2015, 8, 8292-8303. [CrossRef]

16. Sáez del Bosque, I.F.; Van den Heede, P.; De Belie, N.; Sanchez de Rojas, M.I.; Medina, C. Carbonation of concrete with construction and demolition waste based recycled aggregates and cement with recycled content. Constr. Build. Mater. 2020, 234, 117336. [CrossRef]

17. Barreto Santos, M.; De Brito, J.; Santos Silva, A. A Review on Alkali-Silica Reaction Evolution in Recycled Aggregate Concrete. Materials 2020, 13, 2625. [CrossRef]

18. Joseph, A.M.; Van den Heede, P.; Snellings, R.; Van Brecht, A.; Grünewald, S.; Matthys, S.; De Belie, N. Preliminary Investigation on the effect of cement replacement by residues from the incineration of non-hazardous waste on strength and Alkali Silica reaction. In Proceedings of the 14th International Conference on Durability of Building Materials and Components (XIV DBMC) (Vol. PRO 107), Ghent University, Gent, Belgium, 29-31 May 2017; De Schutter, G., De Belie, N., Janssens, A., Van Den Bossche, N., Eds.; RILEM Publications S.A.R.L.: Paris, France, 2017. Available online: http://hdl.handle.net/1854/LU8552394 (accessed on 16 October 2020).

19. Argiz, C.; Menéndez, E.; Sanjuán, M.A.; Moragues, A. Alkali-silica resistance of coal bottom ash mortars. In ICCS16 Concrete Sustainability, Proceedings of the Second International Conference on Concrete Sustainability, ICCS16, Madrid, Spain, 13-15 June 2016; Gálvez, J.C., Ed.; International Center for Numerical Methods in Engineering (CIMNE): Barcelona, Spain, 2016; pp. 350-360.

20. Chen, X.; Zhou, S.; Zhang, H.; Hui, Y. Alkali silicate reaction of cement mortar with cattle manure ash. Constr. Build. Mater. 2019, 203, 722-733. [CrossRef]

21. Abbas, S.; Kazmi, S.M.S.; Munir, M.J. Potential of rice husk ash for mitigating the alkali-silica reaction in mortar bars incorporating reactive aggregates. Constr. Build. Mater. 2017, 132, 61-70. [CrossRef]

22. Wang, H.; Wu, D.; Mei, Z. Effect of fly ash and limestone powder on inhibiting alkali aggregate reaction of concrete. Constr. Build. Mater. 2019, 210, 620-626. [CrossRef]

23. Yazıc1, H.; Beglarigale, A.; Felekoğlu, K.T.; Türkel, S. Comparing the alkali-silica reaction mitigation potential of admixtures by using different accelerated test methods. Constr. Build. Mater. 2019, 197, 597-614. [CrossRef]

24. Chen, H.; Soles, J.A.; Malhotra, V.M. Investigations of supplementary cementing materials for reducing alkali-aggregate reactions. Cem. Concr. Compos. 1993, 15, 75-84. [CrossRef]

25. Thomas, M.D.A. The effect of supplementary cementing materials on alkali- silica reaction: A review. Cem. Concr. Res. 2011, 41, 1224-1231. [CrossRef]

26. Aquino, W.; Lange, D.A.; Olek, J. The influence of metakaolin and silica fume on the chemistry of alkali-silica reaction products. Cem. Concr. Compos. 2001, 23, 485-493. [CrossRef]

27. Shehata, M.H.; Thomas, M.D.A. Use of ternary blends containing silica fume and fly ash to suppress expansion due to alkali-silica reaction in concrete. Cem. Concr. Res. 2002, 32, 341-349. [CrossRef]

28. Monteiro, P.J.M.; Wang, K.; Sposito, G.; dos Santos, M.C.; de Andrade, W.P. Influence of mineral admixtures on the alkali-aggregate reaction. Cem. Concr. Res. 1997, 27, 1899-1909. [CrossRef]

29. Hong, S.Y.; Glasser, F.P. Alkali sorption by C-S-H and C-A-S-H gels: Part II. Role of alumina. Cem. Concr. Res. 2002, 32, 1101-1111. [CrossRef]

30. Bickmore, B.R.; Nagy, K.L.; Gray, A.K.; Brinkerhoff, A.R. The effect of $\mathrm{Al}(\mathrm{OH})^{4-}$ on the dissolution rate of quartz. Geochim. Cosmochim. Acta 2006, 70, 290-305. [CrossRef]

31. Sang, J.C.; Jakubic, R.F.; Barkatt, A.; Saad, E.E. The interaction of solutes with silicate glass and its effect on dissolution rates. J. Non-Cryst. Solids 1994, 167, 158-171. [CrossRef]

32. European Committee for Standardization (CEN). EN 197-1:2011. Cement_Part. 1: Composition, Specifications and Conformity Criteria for Common Cement; European Committee for Standardization (CEN): Brussels, Belgium, 2011. 
33. Spanish Association for Standardization (UNE). UNE 146508:2018. Test. for Aggregates. Determination of the Alkali-Silica and Alkali-Silicate Potential Reactivity of Aggregates. Accelerated Mortar Bar Test.; Spanish Association for Standardization (UNE): Madrid, Spain, 2018.

34. European Committee for Standardization (CEN). EN 196-2:2014. Method of Testing Cement_Part. 2: Chemical Analysis of Cement; European Committee for Standardization (CEN): Brussels, Belgium, 2014.

35. Menéndez, E.; García-Rovés, R.; Ruiz, S. Alkali release from aggregates: Contribution to ASR. Proc. Inst. Civ. Eng. Civ. Eng. Construc. Mater. 2016, 169, 206-214. [CrossRef]

36. Spanish Association for Standardization (UNE). EN 196-1:2016. Methods of Testing Cement-Part. 1: Determination of Strength; Spanish Association for Standardization (UNE): Madrid, Spain, 2016.

37. Spanish Association for Standardization (UNE). UNE 83980:2014. Concrete Durability. Test. Methods. Determination of the Water Absorption, Density and Accessible Porosity for Water in Concrete; Spanish Association for Standardization (UNE): Madrid, Spain, 2014.

38. American Society for Testing and Materials (ASTM) International. ASTM C-1260-14. Standard Test. Method for Potential Alkali Reactivity of Aggregates (Mortar-Bar Method); ASTM International: West Conshohocken, PA, USA, 2014.

39. Spanish Association for Standardization (UNE). UNE 80113:2013. Test. Methods of Cements. Physical Analysis. Determination of the Autoclave Expansion; Spanish Association for Standardization (UNE): Madrid, Spain, 2013.

40. Papadakis, V.G. Experimental investigation and theoretical modeling of silica fume activity in concrete. Cem. Concr. Res. 1999, 29, 79-86. [CrossRef]

41. Skibsted, J.; Snellings, R. Reactivity of supplementary cementitious materials (SCMs) in cement blends. Cem. Concr. Res. 2019, 124, 105799. [CrossRef]

42. Yogendran, V.; Langan, B.W.; Ward, M.A. Hydration of cement and silica fume paste. Cem. Concr. Res. 1991, 21, 691-708. [CrossRef]

43. Mitchell, D.R.G.; Hinczak, I.; Day, R.A. Interaction of silica fume with calcium hydroxide solutions and hydrated cement pastes. Cem. Concr. Res. 1998, 28, 1571-1584. [CrossRef]

44. Sanjuán, M.A.; Argiz, C.; Gálvez, J.C.; Reyes, E. Combined effect of nano-SiO $\mathrm{O}_{2}$ and nano- $\mathrm{Fe}_{2} \mathrm{O}_{3}$ on compressive strength, flexural strength, porosity and electrical resistivity in cement mortars. Mater. Construcc. 2018, 68, e150. [CrossRef]

45. Sanjuán, M.A.; Argiz, C.; Gálvez, J.C.; Moragues, A. Effect of silica fume fineness on the improvement of Portland cement strength performance. Constr. Build. Mater. 2015, 96, 55-64. [CrossRef]

46. Huang, C.L.; Feldman, R.F. Hydration reactions in Portland cement-silica fume blends. Cem. Concr. Res. 1985, 15, 585-592. [CrossRef]

47. Marzouk, H.; Langdon, S. The effect of alkali-aggregate reactivity on the mechanical properties of high and normal strength concrete. Cem. Concr. Compos. 2003, 25, 549-556. [CrossRef]

48. Giaccio, G.; Zerbino, R.; Ponce, J.M.; Batic, O.R. Mechanical behavior of concretes damaged by alkali-silica reaction. Cem. Concr. Res. 2008, 38, 993-1004. [CrossRef]

49. Sanchez, L.F.M.; Fournier, B.; Jolin, M.; Bastien, J. Evaluation of the stiffness damage test (SDT) as a tool for assessing damage in concrete due to ASR: Test loading and output responses for concretes incorporating fine or coarse reactive aggregates. Cem. Concr. Res. 2014, 56, 213-229. [CrossRef]

50. Bektas, F.; Wang, K. Performance of ground clay brick in ASR-affected concrete: Effects on expansion, mechanical properties and ASR gel chemistry. Cem. Concr. Compos. 2012, 34, 273-278. [CrossRef]

51. Yurtdas, I.; Chen, D.; Hu, D.W.; Shao, J.F. Influence of alkali silica reaction (ASR) on mechanical properties of mortar. Constr. Build. Mater. 2013, 47, 165-174. [CrossRef]

52. Haruehansapong, S.; Pulngern, T.; Chucheepsakul, S. Effect of the particle size of nanosilica on the compressive strength and the optimum replacement content of cement mortar containing nano- $\mathrm{SiO}_{2}$. Constr. Build. Mater. 2014, 50, 471-477. [CrossRef]

53. Kong, D.; Du, X.; Wei, X.; Zhang, H.; Yang, Y.; Shah, S.P. Influence of nano-silica agglomeration on microstructure and properties of the hardened cement-based materials. Constr. Build. Mater. 2012, 37, 707-715. [CrossRef]

54. Tashima, M.M.; Soriano, L.; Monzó, J.; Borrachero, M.V.; Akasaki, J.L.; Payá, J. New method to assess the pozzolanic reactivity of mineral admixtures by means of $\mathrm{pH}$ and electrical conductivity measurements in lime:pozzolan suspensions. Mater. Construcc. 2014, 64, e032. [CrossRef] 
55. Bérubé, A.; Duchesne, J. Does silica fume merely postpone expansion due to alkali-aggregate reactivity? Constr. Build. Mater. 1993, 7, 137-143. [CrossRef]

56. Cheng-yi, H.; Feldman, R.F. Influence of silica fume on the microstructural development in cement mortars. Cem. Concr. Res. 1985, 15, 285-294. [CrossRef]

57. Choi, Y.C.; Choi, S. Alkali-silica reactivity of cementitious materials using ferro-nickel slag fine aggregates produced in different cooling conditions. Constr. Build. Mater. 2015, 99, 279-287. [CrossRef]

58. Chappex, T.; Scrivener, K. The Influence of Aluminium on the Dissolution of Amorphous Silica and its Relation to Alkali Silica Reaction. Cem. Concr. Res. 2012, 42, 1513-1523. [CrossRef]

59. Dent Glasser, L.S.; Kataoka, N. The Chemistry of 'Alkali-Aggregate' Reaction. Cem. Concr. Res. 1981, 11, 1-9. [CrossRef]

60. Niibori, Y.; Kunita, M.; Tochiyama, O.; Chida, T. Dissolution Rates of Amorphous Silica in Highly Alkaline Solution. J. Nucl. Sci. Technol. 2000, 37, 349-357. [CrossRef]

61. Stone, W.E.E.; El Shafei, G.M.S.; Sanz, J.; Selim, S.A. Association of Soluble Aluminum Ionic Species With a Silica-gel Surface: A Solid-State NMR Study. J. Phys. Chem. 1993, 97, 10127-10132. [CrossRef]

62. Sanjuán, M.A.; Estévez, E.; Argiz, C. Alkali Ion Concentration Estimations in Cement Paste Pore Solutions. Appl. Sci. 2019, 9, 992. [CrossRef]

63. Ramlochan, T.; Thomas, M.D.A.; Hooton, R.D. The effect of pozzolans and slag on the expansion of mortars cured at elevated temperature: Part II: Microstructural and microchemical investigations. Cem. Concr. Res. 2004, 34, 1341-1356. [CrossRef]

64. Ichikawa, T. Alkali-silica reaction, pessimum effects and pozzolanic effect. Cem. Concr. Res. 2009, 39, 716-726. [CrossRef]

65. Bleszynski, R.F.; Thomas, M.D. Microstructural studies of alkali-silica reaction in fly ash concrete immersed in alkaline solutions. Adv. Cem. Mater. 1998, 7, 66-78. [CrossRef]

Publisher's Note: MDPI stays neutral with regard to jurisdictional claims in published maps and institutional affiliations.

(C) 2020 by the authors. Licensee MDPI, Basel, Switzerland. This article is an open access article distributed under the terms and conditions of the Creative Commons Attribution (CC BY) license (http://creativecommons.org/licenses/by/4.0/). 